Article

\title{
Citrus hystrix Extracts Protect Human Neuronal Cells against High Glucose-Induced Senescence
}

\author{
Nattaporn Pattarachotanant ${ }^{1,2}$ and Tewin Tencomnao ${ }^{1,2, *}$ \\ 1 Department of Clinical Chemistry, Faculty of Allied Health Sciences, Chulalongkorn University, \\ Bangkok 10330, Thailand; nat.ahs11@gmail.com \\ 2 Age-Related Inflammation and Degeneration Research Unit, Chulalongkorn University, \\ Bangkok 10330, Thailand \\ * Correspondence: tewin.t@chula.ac.th; Tel.: +66-2-218-1533
}

Received: 5 August 2020; Accepted: 23 September 2020; Published: 30 September 2020

check for updates

\begin{abstract}
Citrus hystrix $(\mathrm{CH})$ is a beneficial plant utilized in traditional folk medicine to relieve various health ailments. The antisenescent mechanisms of $\mathrm{CH}$ extracts were investigated using human neuroblastoma cells (SH-SY5Y). Phytochemical contents and antioxidant activities of $\mathrm{CH}$ extracts were analyzed using a gas chromatograph-mass spectrometer (GC-MS), 2,2-diphenyl-1-picryl-hydrazyl-hydrate (DPPH) assay and 2,2'-azino-bis (3-ethylbenzthiazoline-6-sulphonic acid) (ABTS) assay. Effects of $\mathrm{CH}$ extracts on high glucose-induced cytotoxicity, reactive oxygen species (ROS) generation, cell cycle arrest and cell cycle-associated proteins were assessed using a 3-(4,5-Dimethylthiazol-2-yl)-2,5-diphenyltetrazolium bromide tetrazolium (MTT) assay, non-fluorescent $2^{\prime}, 7^{\prime}$-dichloro-dihydrofluorescein diacetate $\left(\mathrm{H}_{2} \mathrm{DCFDA}\right)$ assay, flow cytometer and Western blot. The extracts protected neuronal senescence by inhibiting ROS generation. $\mathrm{CH}$ extracts induced cell cycle progression by releasing senescent cells from the G1 phase arrest. As the Western blot confirmed, the mechanism involved in cell cycle progression was associated with the downregulation of cyclin D1, phospho-cell division cycle 2 (pcdc2) and phospho-Retinoblastoma $(\mathrm{pRb})$ proteins. Furthermore, the Western blot showed that extracts increased Surtuin 1 (SIRT1) expression by increasing the phosphorylation of Glyceraldehyde 3-phosphate dehydrogenase (GAPDH). Collectively, $\mathrm{CH}$ extracts could protect high glucose-induced human neuronal senescence by inducing cell cycle progression and up-regulation of SIRT1, thus leading to the improvement of the neuronal cell functions.
\end{abstract}

Keywords: Citrus hystrix; neuronal senescence; high glucose; SIRT1; cyclin D1; pcdc2; pRb; SH-SY5Y

\section{Introduction}

Hyperglycemia is a key characteristic and risk factor that triggers neuronal damage, leads to encephalopathy and causes the development of Diabetes mellitus (DM)-associated neurodegenerative diseases through the induction of neuronal senescence [1-4]. The incidence of most neurodegenerative diseases, such as Alzheimer's (AD) and Parkinson's disease (PD), has been shown to increase exponentially with advancing hyperglycemia and neuronal senescence. Hyperglycemia results in damage of brain structure and is closely related with the development of cognitive impairment and dementia, thus increasing amyloid beta accumulation [5]. Hyperglycemia can cause neuroinflammation, oxidative stress and cell cycle arrest. Cell cycle arrest is an important process associated with neuronal senescence. In replicatively senescent cells, the cell cycle is arrested at the G1 and/or G2 phase [6,7]. Cell cycle regulation is very complex and there are many proteins required for cell cycle progression.

Retinoblastoma $(\mathrm{Rb})$ is a tumor suppressor that is a major regulator of the G1/S transition. $\mathrm{Rb}$ can be phosphorylated by cyclin/cyclin-dependent kinases (CDKs) and forms a complex transcription 
factor E2F to control cell progression through the G1 phase [8].The ability of phospho-Retinoblastoma $(\mathrm{pRb})$ to control the cell cycle has been attributed to E2F suppression [9].

Moreover, there are many CDKs that control the cell cycle, most prominently among them cdk 1 or cell division cycle protein 2 (cdc2). The cdc2 level is high in S and G2 but low in G1. Cdc2 can form a complex with both cyclin A and cyclin B for S phase and G2/M transition control, respectively [10].

Cyclin D1 (G1 cyclin regulatory partner) is an important protein that controls cell cycle progression. Many researches indicated that down-regulation of cyclin D1 causes G1 cell cycle can arrest by reducing $\mathrm{Rb}$ phosphorylation [11-14].

Surtuin 1 (SIRT1) is a nicotinamide dinucleotide (NAD+)-dependent deacetylases. SIRT1 plays an important role in inhibiting cell senescence and extending the lifespan of organisms [15-17]. Moreover, it is an essential factor in the regulation of many processes in cells such as DNA repair, chromatin structure, metabolism, inflammation and cancer [18].

Citrus hystrix $(\mathrm{CH})$, called kaffir lime, is a useful tropical plant native to Southeast Asia. It is a small perennial plant with a hard trunk, smooth bark, smooth trunk and spiny branches. It has green, aromatic and distinctively shaped double leaves. Its fruit is either a single or a bunch. Fresh fruits are rough and green and yellow after ripened. It is commonly used as a very popular ingredient in many dishes. For traditional medicine, whole fruits are used for treating various inflammatory aliments, fever, headache, bad breath, digestion, flu and sore throats [19]. The previous phytochemical report showed that this plant contains various phytoconstituents such as high phenolic, flavonoid, alkaloid, tannins, glycerolglycolipids, tocopherols and furanocoumarins in several parts of $\mathrm{CH}$, such as leaf, peel and juice [20]. These phytochemical compounds exhibited many advantages, such as antioxidant, antibacterial, antifungal, anticholinesterase, anticancer, cardioprotective and antidiabetic activities [21-23].

Phytochemical compounds in $\mathrm{CH}$, including citronellal, citronellol, caryophyllene, nerolidol, phytol, ethyl palmitate, sitosterol and $\alpha$-terpineol and their beneficial effects have been previously described and prompted this investigation.

Citronellal was effective against several pathogenic bacteria and fungi [24-26]. It had the potential to speed up the healing process of Candida-infected wounds in a diabetic mouse model [27] and it could decrease the cholesterol level in rats [28]. Furthermore, it had high antioxidant activities [29].

Citronellol is a natural component of citronella oil. It is widely used as an effective mosquito repellent and is used in perfume and beauty products. Specific pharmacological effects for citronellol include antinociceptive activity and anti-inflammatory effects [30]. It provides neuroprotective activity [31], hypotensive and vasorelaxant effects [32].

Caryophyllene is found in numerous essential oils and has a high potential to treat or prevent hepatic injury and neuroinflammation [33-35].

Nerolidol is found in essential oils of many types of plants and flowers and is known for various medicinal properties, including neuroprotective effects [36], antimicrobial activities [37], anti-biofilm activity [38], anti-fungal activities [39,40].

Phytol is widely used as a food additive and a precursor to phylloquinol (vitamin K), tocopherol (vitamin E) and fatty acid phytyl ester production. In the medicinal field, it exerts an anti-inflammatory effect and redox-protective activity [41].

Ethyl palmitate has anti-inflammatory activities [42].

Sitosterol, a phytosterol (plant sterols), lowers the level of serum low-density lipoprotein cholesterol (LDL-C) and the absorption of intestinal cholesterol [43,44]. It also exerts anti-Alzheimer's activity [45] and antioxidant activity [46,47]. Additionally, it can prevent glutamate and $\beta$-amyloid toxicity [48].

$\alpha$-Terpineol exhibited anti-hypertension, antiproliferation, anti-inflammation, anti-bacteria and antioxidant. Moreover, it could re-establish insulin sensitivity [49-53].

In this study, gallic acid (GA) was used as a positive control. GA has emerged as a strong antioxidant found in fruits and vegetables. GA showed the anti-aging activity on skin [54,55], 
anti-senescence accelerated mice [56], anti-dementia [57], anti-diabetes [58,59] and neuroprotective effect $[24,60]$.

The aim of this study was to investigate the mechanism for antisenescent activity of $\mathrm{CH}$ extracts on a human neuroblastoma cell line (SH-SY5Y). The advantage may be useful for developing alternative medicines to prevent neuronal senescence.

\section{Results}

\subsection{Antioxidant Properties and Total Phenolic and Flavonoid Contents}

In this study, Citrus hystrix peels and leaves were designated as CHP and CHL, respectively. To investigate the free radical scavenging capacities of CHP and CHL, we used a 2,2-diphenyl-1-picryl-hydrazyl-hydrate or DPPH assay, as well as a 2,2'-azino-bis (3-ethylbenzthiazoline-6-sulphonic acid) or ABTS assay. Strong antioxidant activity was found in both CHP and CHL extracts. In CHL extract, we found high phenolic (2134.48 $\pm 1.06 \mathrm{mg}(\mathrm{GA}) / \mathrm{g}$ of dry weigh) and flavonoid $(2856.15 \pm 1.24 \mathrm{mg}(\mathrm{QE}) / \mathrm{g}$ of dry weigh) contents. Table 1 shows free radical scavenging activity data using a DPPH scavenging assay. In Table 2, we show free radical scavenging activity data using an ABTS scavenging assay. Table 3 shows total phenolic and flavonoid content data.

Table 1. Free radical scavenging activities of ethanolic extracts of Citrus hystrix $(\mathrm{CH})$ using a 2,2-diphenyl-1-picryl-hydrazyl-hydrate (DPPH) scavenging assay.

\begin{tabular}{ccc}
\hline Sample & $\begin{array}{c}\text { \% Radical Scavenging Activity } \\
\text { (of } \mathbf{1} \mathbf{~ m g} / \mathbf{m L} \text { Extract) }\end{array}$ & mg VCEAC/g Dry Weight Sample \\
\hline CHP & $14.98 \pm 5.25$ & $210.06 \pm 11.95$ \\
CHL & $15.36 \pm 6.79$ & $238.89 \pm 12.25$ \\
\hline \multicolumn{2}{c}{}
\end{tabular}

Table 2. Free radical scavenging activities of ethanolic extracts of $\mathrm{CH}$ using a 2,2'-azino-bis (3-ethylbenzthiazoline-6-sulphonic acid) (ABTS) scavenging assay.

\begin{tabular}{ccc}
\hline Sample & $\begin{array}{c}\text { \% Radical Scavenging Activity } \\
\text { (of } \mathbf{1} \mathbf{~ m g} / \mathbf{m L} \text { extract) }\end{array}$ & mg VCEAC/g Dry Weight Sample \\
\hline CHP & $90.38 \pm 0.11$ & $3063.67 \pm 3.71$ \\
CHL & $65.18 \pm 0.33$ & $2219.99 \pm 11.12$ \\
\hline \multicolumn{3}{c}{ VCEAC: Vitamin C equivalent antioxidant capacity. }
\end{tabular}

Table 3. Total phenolic and flavonoid contents of ethanolic extracts of $\mathrm{CH}$.

\begin{tabular}{ccc}
\hline Sample & $\begin{array}{c}\text { Total Phenolic } \\
(\mathbf{m g}(G A) / \mathbf{g} \text { of Dry Weight })\end{array}$ & $\begin{array}{c}\text { Total Flavonoid } \\
\mathbf{( m g}(\mathbf{Q E}) / \mathbf{g} \text { of Dry Weight })\end{array}$ \\
\hline CHP & $1796.55 \pm 1.38$ & $1521.54 \pm 3.54$ \\
CHL & $2134.48 \pm 1.06$ & $2856.15 \pm 1.24$ \\
\hline
\end{tabular}

GA: Gallic acid; QE: Quercetin.

\subsection{Phytochemical Constituents of $\mathrm{CHP}$ and $\mathrm{CHL}$}

The extraction yields of CHP and CHL were $14.17 \%$ and $13.04 \%$, respectively. Gas chromatographmass spectrometer (GC-MS) analysis showed the presence of different phytochemical compounds in both extracts. All peaks in both CHP and CHL extracts were detected and compared the MS data with databases to identify chromatographic peaks. GC-MS chromatograms of CHP and CHL were shown in Figures 1 and 2. In the percentage of compounds, we identified 18 proposed phytochemical constituents in CHP, which is detailed in Table 4. Moreover, in Table 5, we detail 12 proposed phytochemical constituents in CHL. 


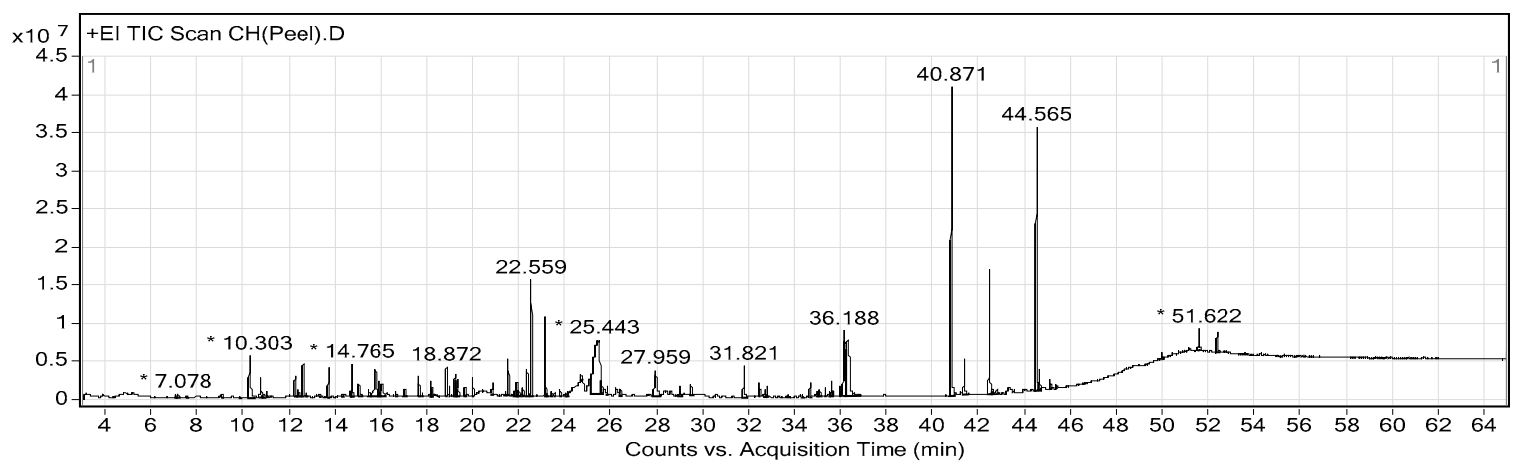

Figure 1. Gas chromatograph-mass spectrometer (GC-MS) chromatogram of Citrus hystrix peels (CHP). * Peaks of proposed phytochemical constituents in CHP were suggested by GC-MS.

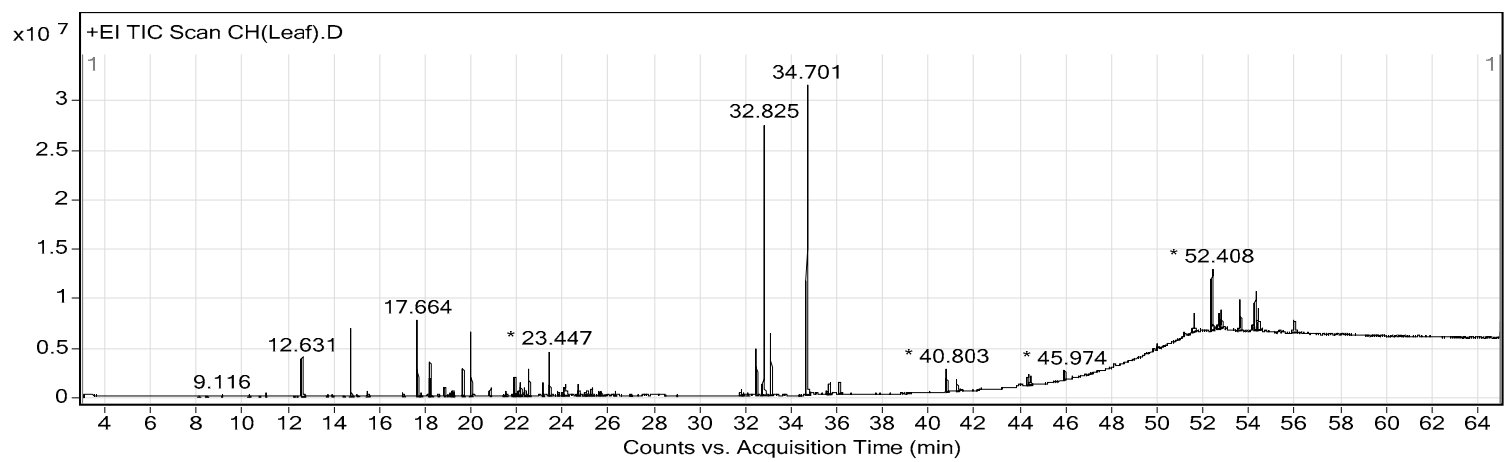

Figure 2. GC-MS chromatogram of Citrus hystrix leaves (CHL). * Peaks of proposed phytochemical constituents in CHL were suggested by GC-MS.

Table 4. Proposed phytochemical constituents in Citrus hystrix peels (CHP) compared with the National Institute of Standards and Technology (NIST) database.

\begin{tabular}{cccccc}
\hline $\begin{array}{c}\text { Peak } \\
\text { No. }\end{array}$ & $\mathbf{R T}$ & $\begin{array}{c}\text { Area } \\
\mathbf{( \% )}\end{array}$ & $\mathbf{M F}$ & $\mathbf{M W}$ & Name of Compound \\
\hline 12 & 12.635 & 0.9 & $\mathrm{C}_{10} \mathrm{H}_{18} \mathrm{O}$ & 154 & Citronellal \\
15 & 13.735 & 0.87 & $\mathrm{C}_{10} \mathrm{H}_{18} \mathrm{O}$ & 154 & C-Terpineol \\
18 & 14.765 & 1.01 & $\mathrm{C}_{10} \mathrm{H}_{20} \mathrm{O}$ & 156 & Citronellol \\
23 & 16.061 & 1.08 & $\mathrm{C}_{8} \mathrm{H}_{14} \mathrm{O}_{3}$ & 158 & $\alpha$-Copaene \\
30 & 18.872 & 0.83 & $\mathrm{C}_{15} \mathrm{H}_{24}$ & 204 & Caryophyllene \\
36 & 20.018 & 0.58 & $\mathrm{C}_{15} \mathrm{H}_{24}$ & 204 & $\beta$-Cubebene \\
40 & 21.559 & 1.13 & $\mathrm{C}_{15} \mathrm{H}_{24}$ & 204 & Cadinene \\
46 & 22.558 & 3.54 & $\mathrm{C}_{15} \mathrm{H}_{24}$ & 204 & Phenol, 2,4-bis(1,1-dimethylethyl)- \\
44 & 22.2 & 0.24 & $\mathrm{C}_{14} \mathrm{H}_{22} \mathrm{O}$ & 206 & 7-Hydroxycoumarin \\
61 & 29.504 & 0.7 & $\mathrm{C}_{9} \mathrm{H}_{6} \mathrm{O}_{3}$ & 162 & n-Hexadecanoic acid \\
62 & 31.821 & 1.23 & $\mathrm{C}_{16} \mathrm{H}_{32} \mathrm{O}_{2}$ & 256 & Hexadecanoic acid, ethyl ester \\
63 & 32.495 & 0.39 & $\mathrm{C}_{18} \mathrm{H}_{36} \mathrm{O}_{2}$ & 284 & Phytol \\
68 & 34.698 & 0.41 & $\mathrm{C}_{20} \mathrm{H}_{40} \mathrm{O}$ & 296 & 7H-Furo(3,2-g)(1)benzopyran-7-one, 9-hydroxy- \\
76 & 36.32 & 6.86 & $\mathrm{C}_{11} \mathrm{H}_{6} \mathrm{O}_{4}$ & 202 & 7H-Furo(3,2-g)(1)benzopyran-7-one, \\
77 & 40.871 & 14.86 & $\mathrm{C}_{16} \mathrm{H}_{14} \mathrm{O}_{5}$ & 286 & 4-(2,3-epoxy-3-methylbutoxy)-, (S)-(-)- \\
78 & 41.405 & 1.37 & $\mathrm{C}_{16} \mathrm{H}_{14} \mathrm{O}_{5}$ & 286 & 4 -(3-Methyl-2-oxobutoxy)-7H-furo(3,2-g)(1)benzopyran-7-one \\
82 & 44.565 & 12.4 & $\mathrm{C}_{16} \mathrm{H}_{16} \mathrm{O}_{6}$ & 304 & 4-(2,3-Dihydroxy-3-methylbutoxy)furo(3,2-g)chromen-7-one \\
88 & 52.412 & 0.81 & $\mathrm{C}_{29} \mathrm{H}_{50} \mathrm{O}$ & 414 & Sitosterol \\
\hline
\end{tabular}

RT: retention time; MF: molecular formula; MW: molecular weight. 
Table 5. Proposed phytochemical constituents in Citrus hystrix leaves (CHL) compared with the NIST database.

\begin{tabular}{cccccc}
\hline $\begin{array}{c}\text { Peak } \\
\text { No. }\end{array}$ & RT & $\begin{array}{c}\text { Area } \\
\mathbf{( \% )}\end{array}$ & $\mathbf{M F}$ & MW & Name of Compound \\
\hline 9 & 12.631 & 2.35 & $\mathrm{C}_{10} \mathrm{H}_{18} \mathrm{O}$ & 154 & Citronellal \\
13 & 14.758 & 3.53 & $\mathrm{C}_{10} \mathrm{H}_{20} \mathrm{O}$ & 156 & Citronellol \\
17 & 17.664 & 4.24 & $\mathrm{C}_{10} \mathrm{H}_{20} \mathrm{O}_{2}$ & 172 & Cyclohexanol, 2-(2-hydroxy-2-propyl)-5-methyl- \\
28 & 20.014 & 3.51 & $\mathrm{C}_{15} \mathrm{H}_{24}$ & 204 & Caryophyllene \\
36 & 22.193 & 0.78 & $\mathrm{C}_{14} \mathrm{H}_{22} \mathrm{O}$ & 206 & Phenol, 2,4-bis(1,1-dimethylethyl)- \\
40 & 23.447 & 2.39 & $\mathrm{C}_{15} \mathrm{H}_{26} \mathrm{O}$ & 222 & 1,6,10-Dodecatrien-3-ol, 3,7,11-trimethyl- \\
55 & 31.918 & 0.19 & $\mathrm{C}_{20} \mathrm{H}_{30} \mathrm{O}_{4}$ & 334 & 1,2-Benzenedicarboxylic acid, butyl octyl ester \\
57 & 32.494 & 2.52 & $\mathrm{C}_{18} \mathrm{H}_{36} \mathrm{O}_{2}$ & 284 & Hexadecanoic acid, ethyl ester \\
61 & 34.701 & 17.3 & $\mathrm{C}_{20} \mathrm{H}_{40} \mathrm{O}$ & 296 & Phytol \\
65 & 40.803 & 1.53 & $\mathrm{C}_{16} \mathrm{H}_{14} \mathrm{O}_{5}$ & 286 & 7H-Furo(3,2-g)(1)benzopyran-7-one, \\
68 & 44.484 & 0.73 & $\mathrm{C}_{16} \mathrm{H}_{16} \mathrm{O}_{6}$ & 304 & $4-(2,3-D i h y d r o x y-3-m e t h y l b u t o x y) f u r o(3,2-g)$ chromen-7-one \\
71 & 52.408 & 4.91 & $\mathrm{C}_{29} \mathrm{H}_{50} \mathrm{O}$ & 414 & Sitosterol \\
\hline \multicolumn{7}{c}{ RT: retention time; MF: molecular formula; MW: molecular weight. }
\end{tabular}

\subsection{Neuronal Senescent Model}

To create a neuronal senescent model, SH-SY5Y cells were induced into an expression of intracellular reactive oxygen species (ROS) by treating cells with 5.55 (control) to $100 \mathrm{mM}$ glucose. In addition, the effect of glucose on cell viability was detected. We found that glucose could significantly increase the percentage of intracellular ROS in a dose-dependent manner after treatment for $24 \mathrm{~h}$ (Figure 3). Moreover, the highest concentration of glucose that had no effect on cell viability was $100 \mathrm{mM}$ (Figure 4). From all results, we used $100 \mathrm{mM}$ glucose to induce neuronal senescence in this model.

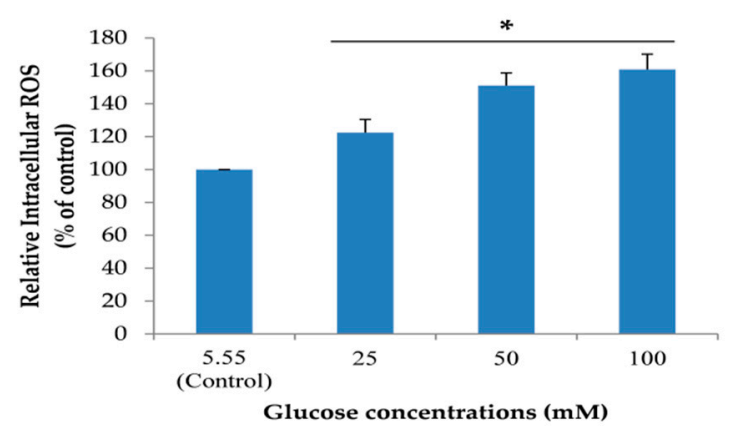

Figure 3. The effect of different concentrations of glucose on intracellular reactive oxygen species (ROS). Relative intracellular ROS level was performed using a microplate reader. Data are mean $\pm \mathrm{SD}, * p<$ 0.05 vs. control. $p$ values were $0.03,0.007$ and 0.000 for groups treated with glucose concentrations of 25,50 and $100 \mathrm{mM}$, respectively. 


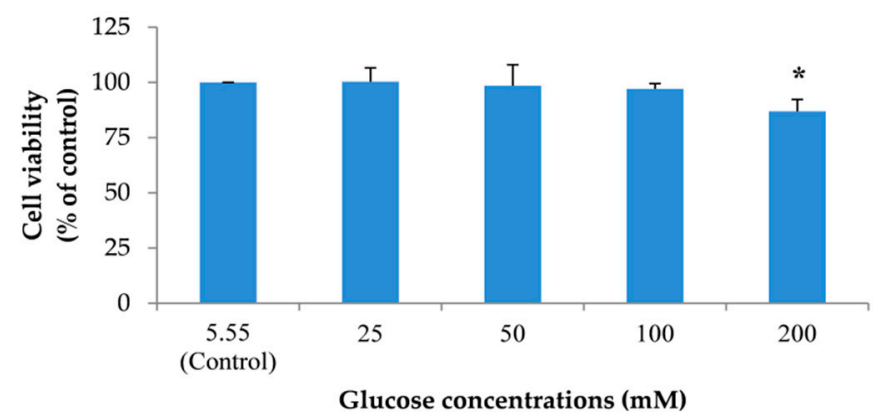

Figure 4. The effect of different concentrations of glucose on SH-SY5Y cell viability. Detection of cell viability was performed using 3-(4,5-Dimethylthiazol-2-yl)-2,5-diphenyltetrazolium bromide tetrazolium (MTT) assay. Data are presented as the means $\pm \mathrm{SD},{ }^{*} p<0.05$ vs. control. $p$ values of $200 \mathrm{mM}$ glucose-treated group was 0.000 .

\subsection{Effects of the Extracts on Cell Viability}

Using the working concentrations of both extracts, CHP and CHL ( 0 to $100 \mu \mathrm{g} / \mathrm{mL}$ ) were prepared. We found that all concentrations of $\mathrm{CHL}$ had no effect on cell viability. For the $\mathrm{CHP}$ effect, the results showed that $\mathrm{CHP}$ at the concentration of 50 and $100 \mu \mathrm{g} / \mathrm{mL}$ could significantly decrease cell viability. As seen in Figure 5, the percentage of cell viability treated with CHP for $24 \mathrm{~h}$ was $85.50 \pm 4.56 \%$ and $72.48 \pm 16.12 \%$ in 50 and $100 \mu \mathrm{g} / \mathrm{mL}$, respectively.

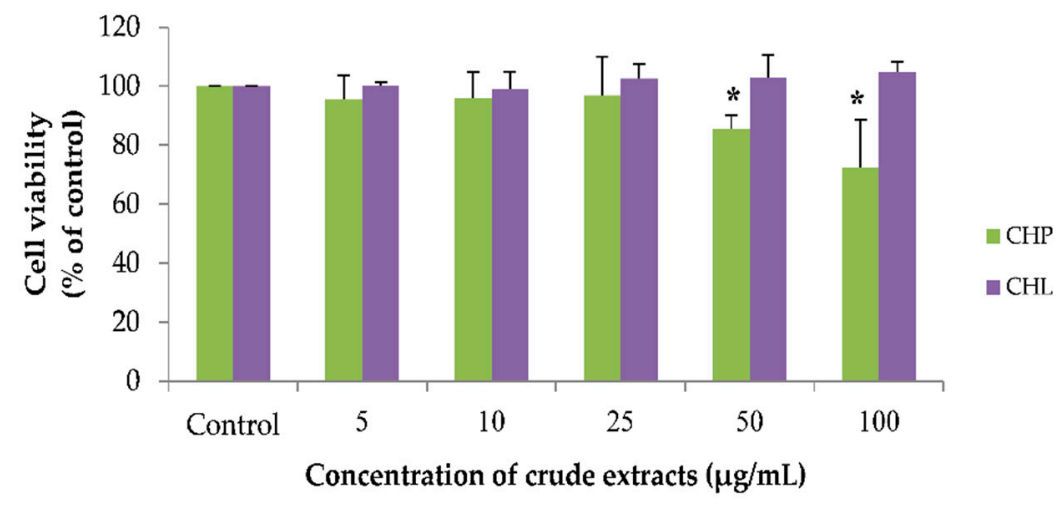

Figure 5. The effect of CHP and CHL on cell viability. Detection of cell viability was performed using an MTT assay. Data are presented as the means $\pm \mathrm{SD}, * p<0.05$ vs. control. $p$ values were 0.018 and 0.030 in groups treated with CHP concentrations of 50 and $100 \mu \mathrm{g} / \mathrm{mL}$, respectively.

\subsection{Effects of the Extracts on Intracellular ROS Reduction}

To examine the effects of CHP and CHL on high glucose-induced intracellular ROS, this experiment was investigated by treating cells with $100 \mathrm{mM}$ glucose alone or combined with different concentrations of CHP $(1,5$ and $10 \mu \mathrm{g} / \mathrm{mL})$ and CHL $(1,5,10$ and $25 \mu \mathrm{g} / \mathrm{mL})$. The dose-response curve of $\mathrm{CH}$ extracts was obtained by isovolumetric additions of $\mathrm{CHP}$ and $\mathrm{CHL}$ solutions of different concentrations so that the DMSO concentration range was from 0.001 to $0.025 \%(v / v)$. We found that both CHP and $\mathrm{CHL}$ at $1 \mu \mathrm{g} / \mathrm{mL}$ could significantly reduce the percentage of high glucose-induced intracellular ROS (Figure 6a,b). However, to clarify the effect of DMSO in CH extracts on intracellular ROS accumulation, cells were treated with 0.001 to $0.025 \%(v / v)$ DMSO alone for $24 \mathrm{~h}$. In the $\mathrm{H}_{2}$ DCFDA assay, we show that the increasing DMSO alone did not affect ROS generation in SH-SY5Y cells (Figure 6c). This result clarified that both $\mathrm{CHP}$ and $\mathrm{CHL}$ extracts appeared to be effective reducing the intracellular ROS accumulation at the concentration of $1 \mu \mathrm{g} / \mathrm{mL}$ but not at higher concentrations was not caused by DMSO. 


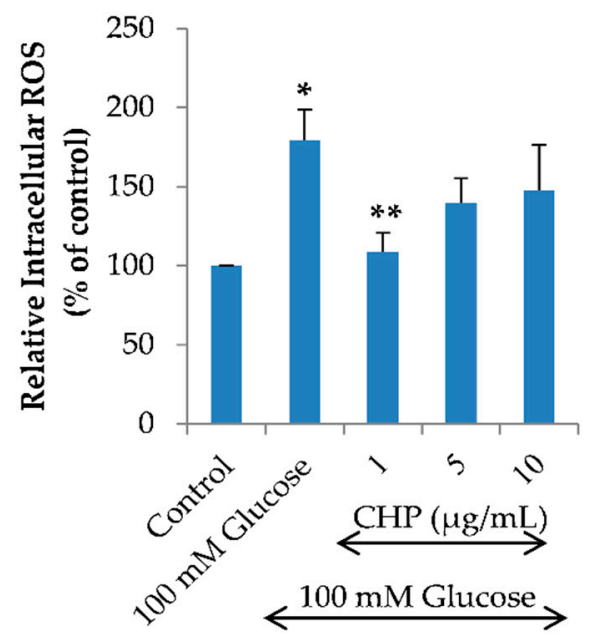

(a)

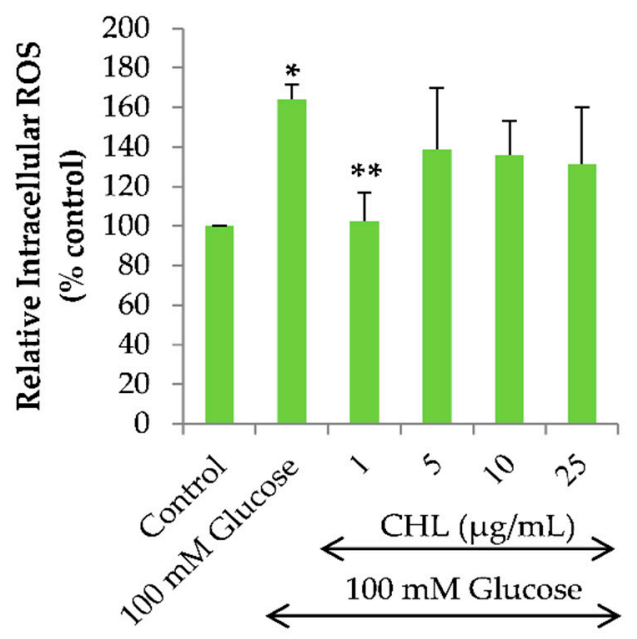

(b)

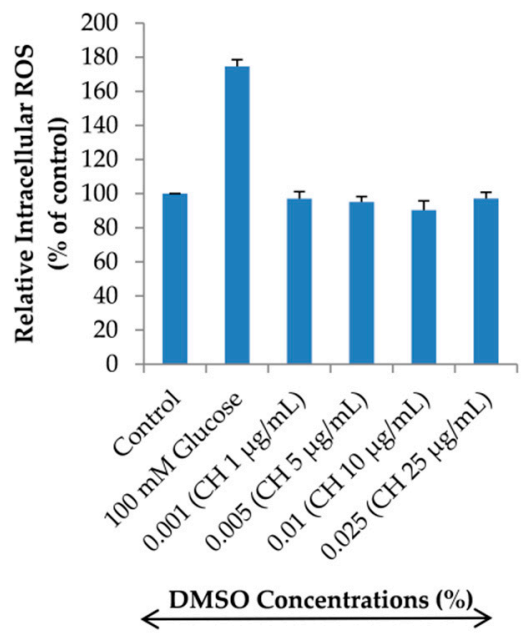

(c)

Figure 6. Effects of the extracts on high glucose-induced ROS accumulation in SH-SY5Y cells. Relative intracellular ROS level of SH-SY5Y cells treated with $100 \mathrm{mM}$ glucose alone or combined with different concentrations for either CHP (a) or CHL (b) for $24 \mathrm{~h}$. The effect of DMSO on relative intracellular ROS level of SH-SY5Y cells treated with $(0.001$ to $0.025 \%(v / v))$ DMSO alone (c). Data are presented as the means $\pm \mathrm{SD},{ }^{*} p<0.05$ vs. control; ${ }^{* *} p<0.05$ vs. $100 \mathrm{mM}$ glucose alone. For CHP, $p$ value was 0.002 in both $100 \mathrm{mM}$ glucose and $1 \mu \mathrm{g} / \mathrm{mL}$ groups. For CHL, $p$ value was 0.000 in both $100 \mathrm{mM}$ glucose and $1 \mu \mathrm{g} / \mathrm{mL}$ groups.

\subsection{Effects of the Extracts on Cell Cycle}

To further understand the ability of both CHP and CHL on neuronal senescence, we determined the activity on cell cycle distribution. Data generated from a flow cytometer demonstrated that the percentage of cells in the G0/G1 phase when treated with $100 \mathrm{mM}$ glucose was significantly higher than in the control group $(p<0.05)$. Moreover, $100 \mathrm{mM}$ glucose arrested cells in the resting phase (G0/G1). The percentage of cells in the G0/G1 phase after treatment combined with $100 \mathrm{mM}$ glucose and $1 \mu / \mathrm{mL}$ of either extract or gallic acid was significantly decreased when compared with the group treated with glucose $(p<0.05)$ (Figure 7). Gallic acid (GA) was used as a positive control in this study. 

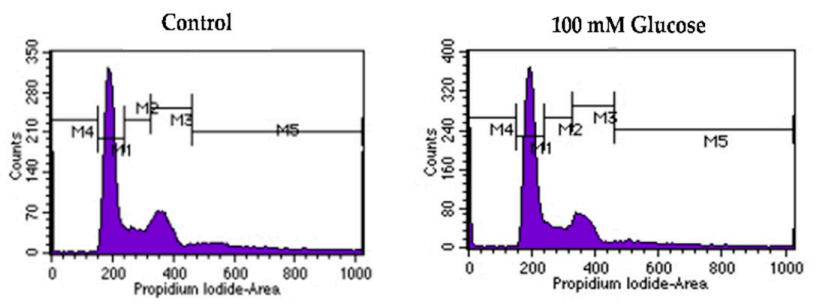

$100 \mathrm{mM}$ Glucose
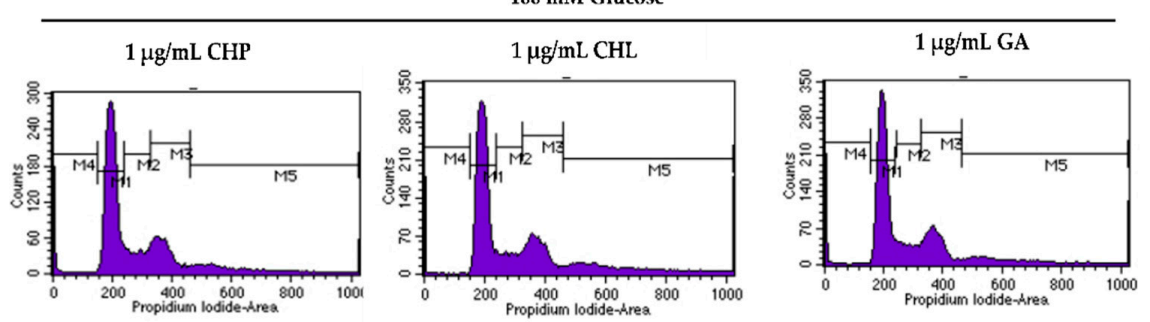

(a) Cell cycle histogram.

\begin{tabular}{|c|c|c|c|c|c|}
\hline $\begin{array}{c}\text { Cell } \\
\text { Population }\end{array}$ & Control & $\begin{array}{l}100 \mathrm{mM} \\
\text { Glucose }\end{array}$ & $\begin{array}{c}100 \mathrm{mM} \\
\text { Glucose } \\
1 \mu \mathrm{g} / \mathrm{mL} \mathrm{CHP} \\
\end{array}$ & $\begin{array}{c}100 \mathrm{mM} \\
\text { Glucose } \\
1 \mu \mathrm{g} / \mathrm{mL} \mathrm{CHL} \\
\end{array}$ & $\begin{array}{c}100 \mathrm{mM} \\
\text { Glucose } \\
1 \mu \mathrm{g} / \mathrm{mL} \mathrm{GA} \\
\end{array}$ \\
\hline G1 & $39.36 \pm 5.91$ & $54.41 \pm 1.69$ * & $40.55 \pm 0.98^{* *}$ & $46.08 \pm 1.29 * *$ & $43.29 \pm 1.78^{* *}$ \\
\hline$S$ & $11.31 \pm 0.9$ & $10.78 \pm 1.87$ & $10.34 \pm 1.54$ & $11.61 \pm 0.33$ & $10.52 \pm 1.06$ \\
\hline G2/M & $31.30 \pm 2.53$ & $31.56 \pm 1.71$ & $29.27 \pm 4.58$ & $29.12 \pm 2.04$ & $27.95 \pm 0.06$ \\
\hline
\end{tabular}

(b) The percentage of cell number

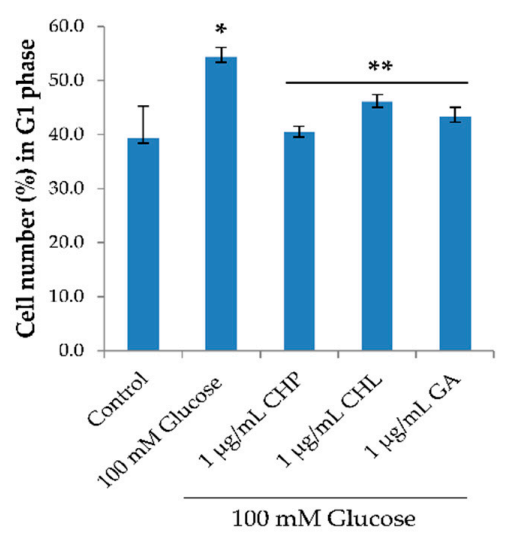

(c) The percentage of cell number

Figure 7. The effect of extracts on the cell cycle. Quantitative determination based on propidium iodide (PI) staining was carried out using a flow cytometer. The results showed (a) cell cycle histogram, (b,c) the percentage of cell numbers. Data are presented as the means $\pm \mathrm{SD},{ }^{*} p<0.05$ vs. control; ${ }^{* *} p<0.05$ vs. $100 \mathrm{mM}$ glucose alone. $p$ values were $0.001,0.001,0.039$ and 0.007 for $100 \mathrm{mM}$ glucose, $\mathrm{CHP}, \mathrm{CHL}$ and GA, respectively.

\subsection{Effect of the Extracts on Cell Cycle-Associated Protein and SIRT1 Expression}

Cell cycle regulation is of critical importance in the senescence process. The cell cycle diagram and the cell numbers carried out in a flow cytometer showed that high glucose may cause cell senescence by interfering cell cycle progression. The extracts could affect high glucose. To confirm this, we investigated the expression of three proteins: cyclin D1 (G1 cyclin regulatory partner), 
$\mathrm{pRb}$ (G1 checkpoint) and pcdc2 (S and G2 checkpoint) using the Western blot. Figure 8, shows the expression of cyclin D1 and pRb was significantly increased when cells were treated with $100 \mathrm{mM}$ of glucose alone ( ${ }^{*} p<0.05$ vs. control). When treated with $1 \mu \mathrm{g} / \mathrm{mL}$ of either CHL or GA, both $\mathrm{pRb}$ and pcdc2 proteins were significantly decreased and only cyclin D1 expression was reduced in response to treatment with $1 \mu \mathrm{g} / \mathrm{mL} \mathrm{CHP} \mathrm{(**} p<0.05$ vs. $100 \mathrm{mM}$ glucose alone).

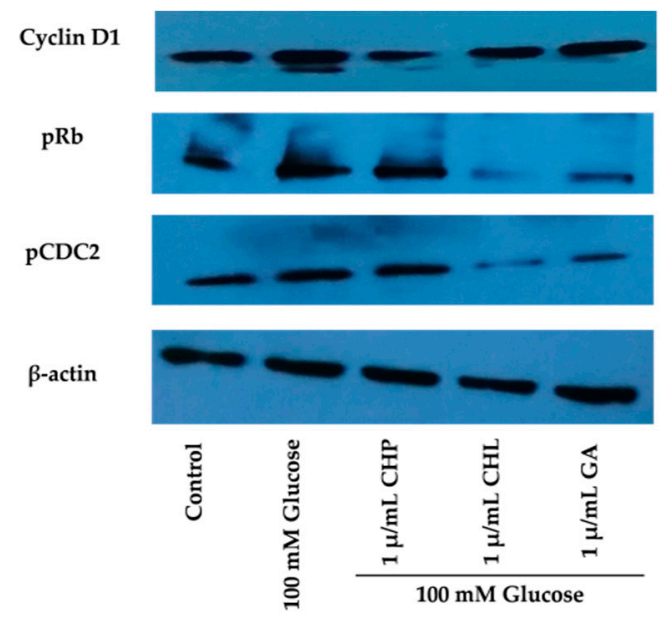

(a)

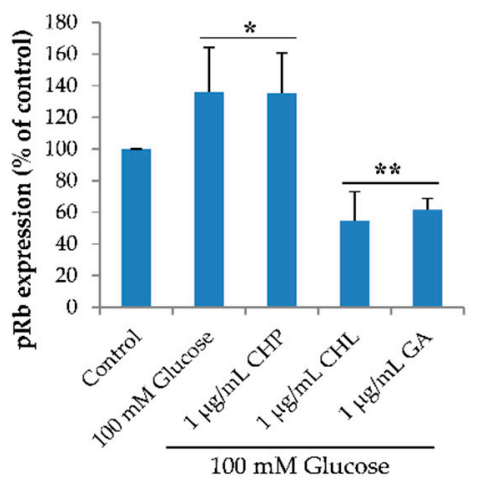

(c)

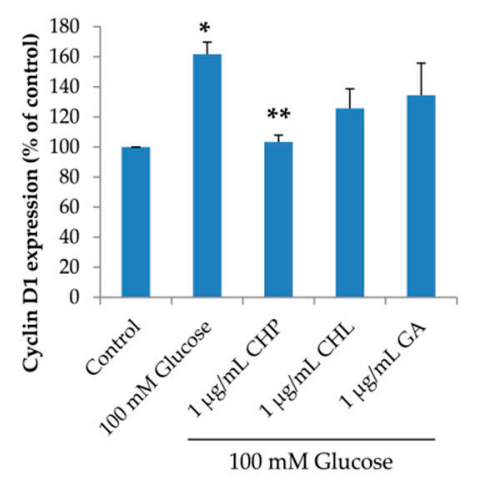

(b)

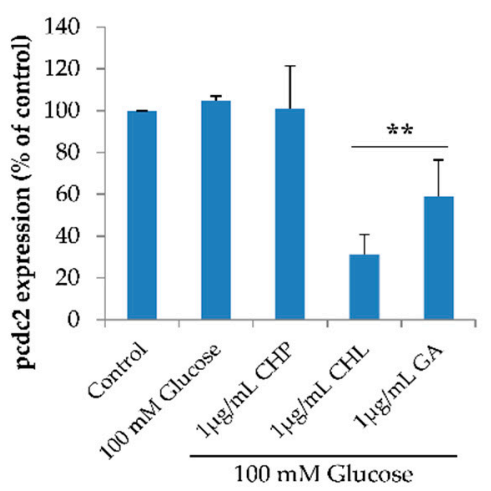

(d)

Figure 8. Cyclin D1, phospho-Retinoblastoma (pRb) and phospho-cell division cycle 2 (pcdc2) expression, as shown in a representative Western blot (a). Normalized values of Cyclin $\mathrm{D}, \mathrm{pRb}$ and pcdc2 against $\beta$-actin ((b), (c) and (d), respectively). The mean \pm SD values of normalized Cyclin $D$, $\mathrm{pRb}$ and pcdc2 expression were obtained from three independent experiments, ${ }^{*} p<0.05$ vs. control; ** $p<0.05$ vs. $100 \mathrm{mM}$ glucose alone. For Cyclin D1, $p$ values were 0.019 and 0.027 for $100 \mathrm{mM}$ glucose and $\mathrm{CHP}$, respectively. For $\mathrm{pRb}, p$ values were $0.037,0.049,0.001$ and 0.002 for $100 \mathrm{mM}$ glucose, $\mathrm{CHP}$, CHL and GA, respectively. For pcdc2, $p$ values were 0.011 and 0.042 for CHL and GA, respectively.

SIRT1 plays an important role in cell cycle and cell senescence. SIRT1 expression is a response to glucose starvation, as it activates GAPDH phosphorylation. As revealed in Figure 9, SIRT1 and GAPDH expression levels were not significantly different between the control and $100 \mathrm{mM}$ glucose-treated groups. In extract-treated groups, CHP, CHL and GA significantly reduced glucose level in cells. When the glucose level was low, GAPDH was phosphorylated and phospho-GAPDH translocated into a nucleus that up-regulated SIRT1 expression. For these reasons, we found that SIRT1 expression significantly increased and decreased GAPDH expression, which was observed in extract-treated cells (** $p<0.05$ vs. $100 \mathrm{mM}$ glucose alone). 


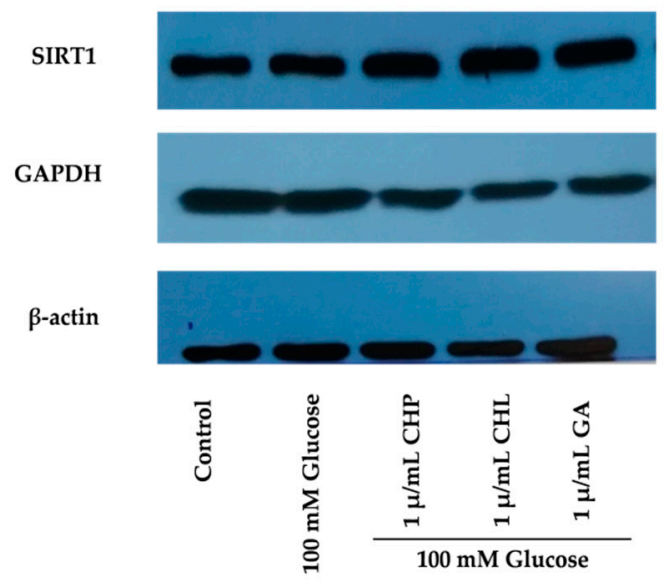

(a)

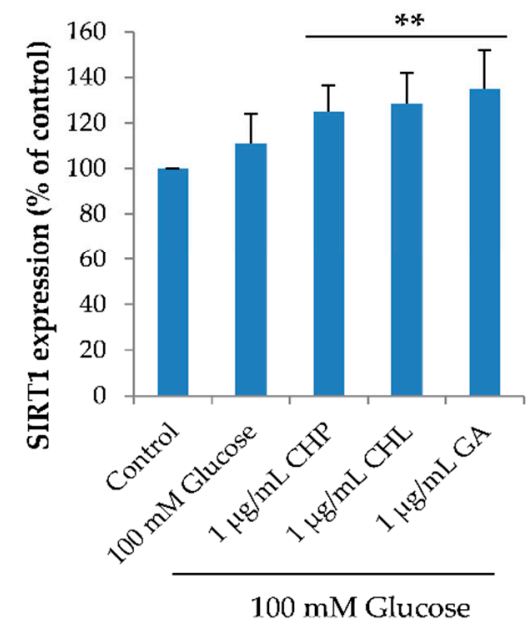

(b)

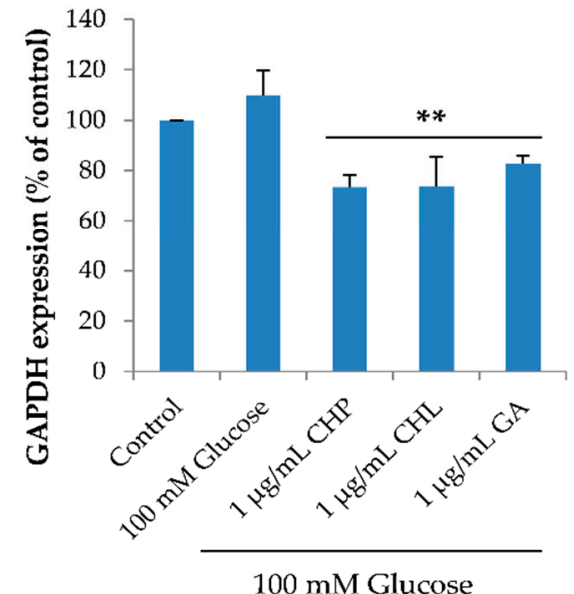

(c)

Figure 9. Surtuin 1 (SIRT1) and Glyceraldehyde 3-phosphate dehydrogenase (GAPDH) expression, as shown in a representative Western blot (a). Normalized values of SIRT1 and GAPDH against $\beta$-actin $((\mathbf{b})$ and $(\mathbf{c}))$. The mean \pm SD values of normalized SIRT1 and GAPDH expression were obtained from three independent experiments, ${ }^{*} p<0.05$ vs. control; ${ }^{* *} p<0.05$ vs. $100 \mathrm{mM}$ glucose alone. For SIRT1, $p$ values were $0.005,0.011$ and 0.005 for $\mathrm{CHP}, \mathrm{CHL}$ and GA, respectively. For GAPDH, $p$ values were $0.001,0.001$ and 0.008 for CHP, CHL and GA, respectively.

\section{Discussion}

Citrus hystrix is a medicinal plant that treats many ailments and it is used in many traditional medicines. Based on DPPH and ABTS assays, high antioxidant properties of its extracts were reported. Furthermore, the phytochemical constituents were analyzed and identified by GC-MS. The spectrum of GC-MS confirmed that CHP and CHL contain a number of various bioactive compounds. The nature and beneficial effects on health of these compounds were discussed in Table 6. 
Table 6. Compound nature and bioactivity of phytochemical constituents in CHP and CHL.

\begin{tabular}{|c|c|c|}
\hline Name of Compound & Compound Nature & Bioactivity \\
\hline Citronellal & Monoterpenoid & $\begin{array}{c}\text { Antibacterial and antifungal activities }[24,40] \\
\text { Wound healing property on chronic diabetic wounds [27] } \\
\text { Relaxing effects }[61,62]\end{array}$ \\
\hline Citronellol & Monoterpene alcohol & Anti-inflammatory and analgesic activities $[30,63]$ \\
\hline Cyclohexanol, 2-(2-hydroxy-2-propyl)-5-methyl- & Monoterpenoid & Insect repellents $[64,65]$ \\
\hline Caryophyllene & Monoterpenes & $\begin{array}{c}\text { Anti-inflammatory pathologies, atherosclerosis and tumors }[35,66,67] \\
\text { Antioxidant activity }[68,69] \\
\text { Analgesic activity }[70,71]\end{array}$ \\
\hline 2,4-bis(1,1-dimethylethyl)Phenol & Phenol & $\begin{array}{l}\text { Antioxidant activity }[72-74] \\
\text { Anti-inflammatory activity }[74,75]\end{array}$ \\
\hline $\begin{array}{c}\text { 1,6,10-Dodecatrien-3-ol, 3,7,11-trimethyl- } \\
\text { or } \\
\text { (Nerolidol) }\end{array}$ & Sesquiterpene alcohol & $\begin{array}{c}\text { Antioxidant activity [76-80] } \\
\text { Anti-inflammatory and analgesic activities [81,82] } \\
\text { Neuroprotective effect [36] }\end{array}$ \\
\hline 1,2-Benzenedicarboxylic acid, butyloctyl ester & Ester & Antioxidant activity [83] \\
\hline $\begin{array}{l}\text { Hexadecanoic acid, ethyl ester } \\
\text { or } \\
\text { (Ethyl palmitate) }\end{array}$ & $\begin{array}{l}\text { Palmitic acid ester } \\
\text { (Fatty acid ethyl ester) }\end{array}$ & $\begin{array}{c}\text { Antioxidant, hypocholesterolemic, anti-androgenic [84] } \\
\text { Anti-inflammatory activities [42] }\end{array}$ \\
\hline Phytol & Diterpene alcohol & Antioxidant and neuroprotective effects $[41,85]$ \\
\hline $\begin{array}{c}\text { 7H-Furo(3,2-g)(1)benzopyran-7-one, } \\
\text { 4-(2,3-epoxy-3-methylbutoxy)-, (S)-(-)- } \\
\text { or } \\
\text { (Heraclenin) }\end{array}$ & Furanocoumarin & Anti-inflammatory activity [86] \\
\hline $\begin{array}{l}\text { 4-(2,3-Dihydroxy-3-methylbutoxy) } \\
\text { furo(3,2-g)chromen-7-one } \\
\text { or } \\
\text { (Oxypeucedanin hydrate oraviprin) }\end{array}$ & Furanocoumarin & $\begin{array}{c}\text { Antioxidant activity } \\
\text { Anticancer activity }[87,88]\end{array}$ \\
\hline Sitosterol & Phytosterol & $\begin{array}{l}\text { Prevention of the coronary heart disease }[43,44] \\
\text { Anti-Alzheimer's activity }[45] \\
\text { Antioxidant activity }[46,47] \\
\text { Prevention of glutamate and } \beta \text {-amyloid toxicity }[48]\end{array}$ \\
\hline
\end{tabular}


Table 6. Cont

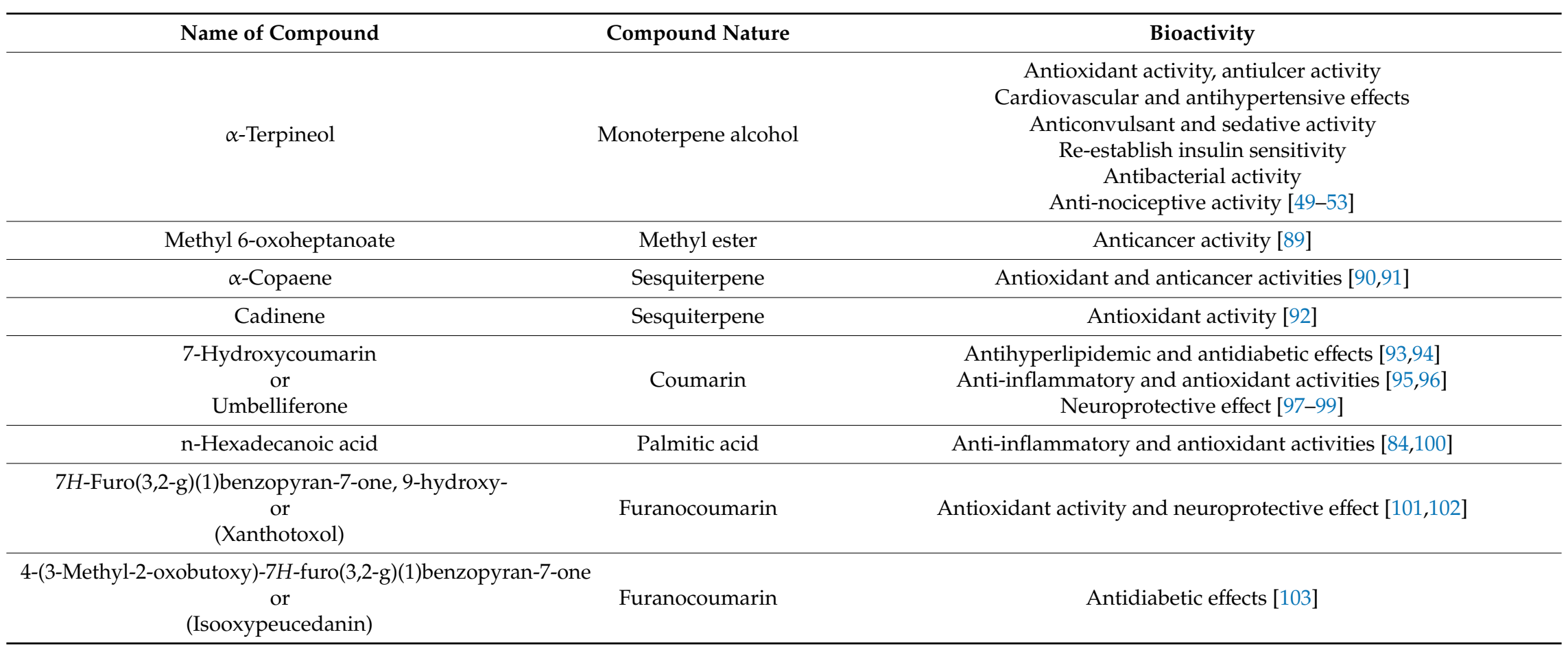


Hyperglycemia is a major cause of diabetes-associated neuronal diseases through cellular senescence. Cellular senescence is the process of an irreversible cell cycle arrest through many mechanisms, that is, inflammation cytokine, oxidative stress and cell cycle checkpoint [104-106]. Further, it causes many age-related chronic diseases such as atherosclerosis, Alzheimer's disease and cancer [107-111]. The antidiabetic and antioxidant activity of $\mathrm{CH}$ and its phytochemical constituents was described earlier in human adipocytes, cataract in streptozotocin-induced diabetic rats [112] and hepatoprotective effect in paracetamol-induced injury in rats [23]. However, the exact pathway of protective effect of $\mathrm{CH}$ on high glucose-induced neuronal senescence was not explored.

Interestingly, CHP and CHL extracts appeared to effectively reduce the intracellular ROS accumulation at the concentration of $1 \mu \mathrm{g} / \mathrm{mL}$ but not at higher concentrations. Notably, it is interesting that CHP and CHL may also possess a pro-oxidant activity when administered at high doses. It is worth noting that contributing factors such as dosage, phytochemical profile and oxidation-reduction potential (ORP) may relate to the balance between the beneficial and deleterious activities [113]. The detail of ORP is described herein biochemical perspective.

Given the effectiveness of both CHP and CHL to decrease ROS induced by high glucose, we hypothesized that both extracts may provide neuronal cell protection against cell cycle arrest induced by high glucose. To test our hypothesis, we first analyzed cell cycle via a flow cytometer.

For flow cytometry results (Figure 7a,b), the percentage of cells at the G1 phase in the $100 \mathrm{mM}$ glucose-treated group significantly increased compared with the control group. In addition, both CHP and CHL extracts significantly decreased the percentage of the cell number in the G1 phase.

To further confirm the effect of CHP and CHL on cell cycle, the expression of cell cycle checkpoint proteins (pRb and cdc2), cyclin D1 and SIRT1 was detected by the Western blot.

Checkpoint processes control the cell cycle to avoid the accumulation of genetic damage. It does so by monitoring DNA integrity and cell growth during G1/S and G2/M transitions. These processes are common to all eukaryotic cells [114]. As Figure 10 shows, in the early and middle points of the G1 phase, $\mathrm{Rb}$ binds to E2F causing cells to arrest. However, in late stage of the G1 phase, Rb is phosphorylated by $\mathrm{CDKs}$ to increase gene transcription and permit cells to enter the $S$ phase. Cyclin/cdc2 complexes control the cell cycle. Cdc2 is high in the S and G2 phases. In the S phase, G2/M transition control binds to cyclin A and cyclin B, respectively. Cyclin/cdc2 complexes are inactive due to Wee1/Myt1 phosphorylation.

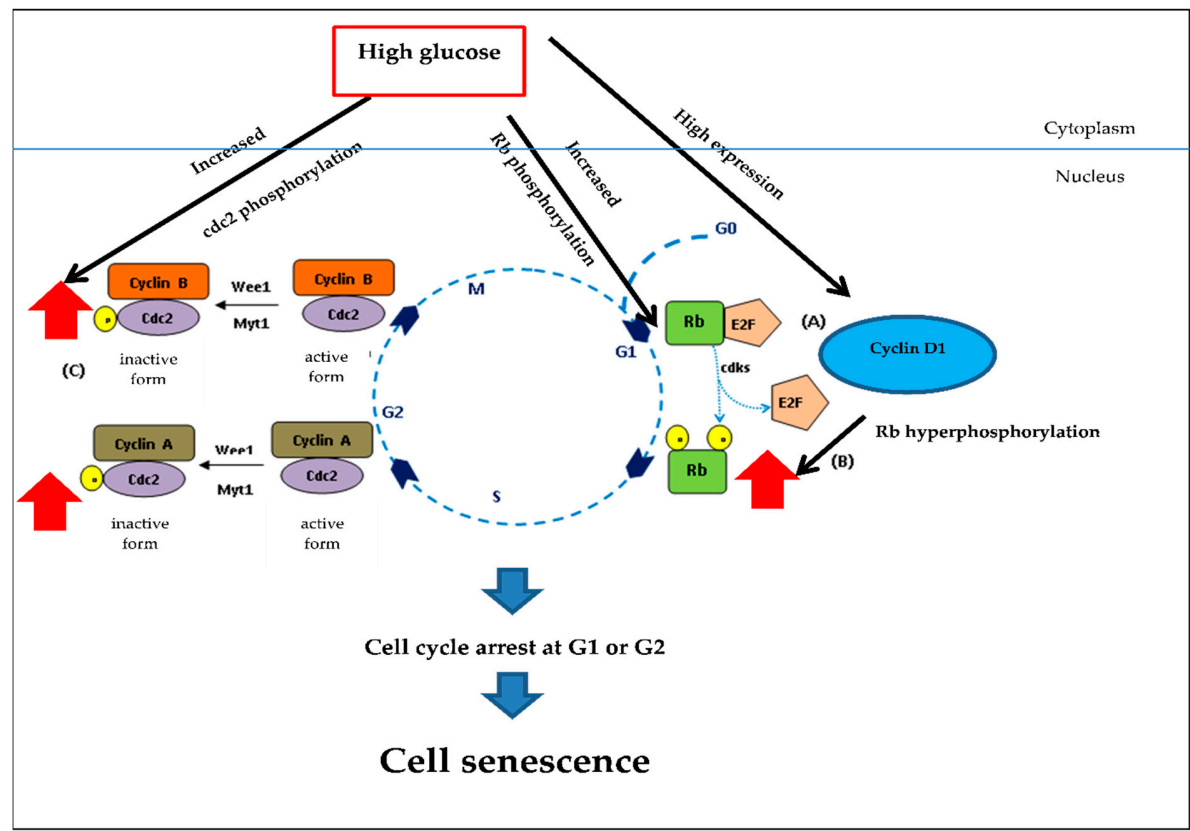

(a)

Figure 10. Cont. 


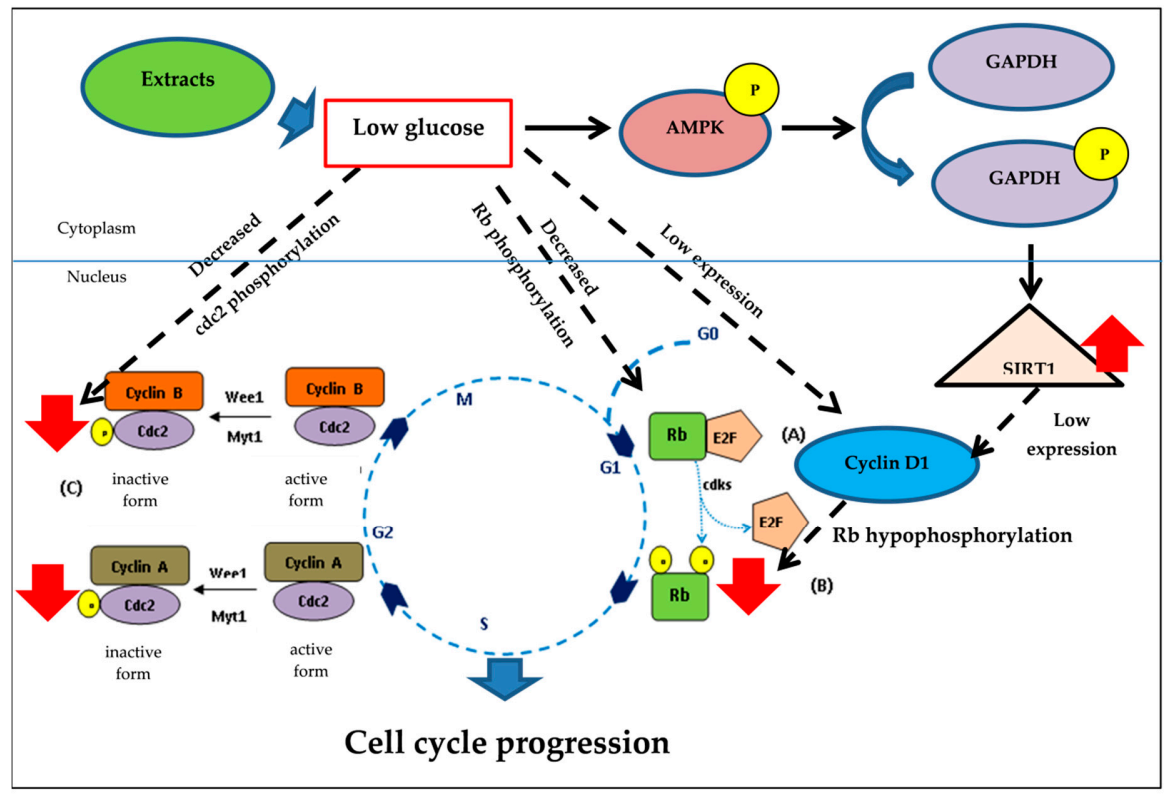

(b)

Figure 10. Underlying mechanisms of CHP and CHL exerts and their anti-senescent activity in SH-SY5Y cells. (a) In hyperglycemia, hyperphosphorylation of Rb induced by high glucose and cyclin D1 caused cell cycle arrest at G1. Hyperphosphorylated Rb failed to assemble with E2F. Furthermore, pcdc2 was an inactive form that caused cell cycle arrest. (b) Both extracts could reduce high glucose level. Low cellular glucose significantly increased GAPDH phosphorylation via AMP-activated protein kinase (AMPK), triggering SIRT1 activation. This mechanism induced the cell cycle progression by decreasing

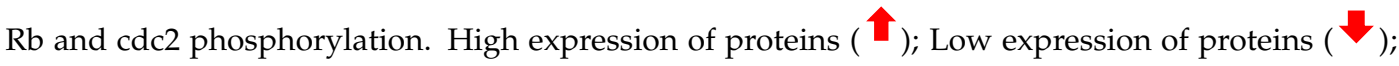
Hyperphosphorylation of proteins $(\rightarrow)$; Hypophosphorylation of proteins $(\overrightarrow{>})$.

The Western blot results demonstrated that high glucose significantly increased cyclin D1, pRb and pcdc2. Increased cyclin D1 could induce phosphorylation of Rb (Figure 10a). Although the pRb/E2F complex permits cell progression in the G1 and S phase, in hyperglycemia, hyperphosphorylation of $\mathrm{Rb}$-induced high glucose and cyclin D1 caused cell cycle arrest at G1. Many studies have indicated that hyperphosphorylated $\mathrm{Rb}$ failed to assemble E2F [115-117]. Furthermore, we found pcdc2 to be an inactive form that caused cell cycle arrest.

Although both CHP and CHL were similarly effective in reducing ROS accumulation, they exerted neuronal cell protection against cell cycle arrest induced by high glucose through different signaling pathways. We observed that CHP significantly decreased only cyclin D1 expression in extract-treated groups, while CHL significantly decreased both $\mathrm{pRb}$ and pcdc2 expression. However, taken together, our results showed that both CHP and CHL could provide neuronal cell protection against cell cycle arrest induced by high glucose.

Noticeably, the difference of the effect on cell-cycle associated protein expression between CHP-treated and CHL-treated groups might be due to the compositional differences of the two extracts, as shown by the GC-MS analysis. GC-MS analysis (Tables 4 and 6) revealed that phytochemical constituents of isooxypeucedanin, $\alpha$-terpineol and umbelliferone were only found in CHP and exerted antidiabetic effect by normalizing blood glucose level and re-establishing insulin sensitivity $[57,58,66]$. The previous studies showed the effect of certain antidiabetic drugs on the cell-cycle through the decrease of cyclin D1 expression [118]. Cyclin D1 is an essential link between cell-cycle and energy control metabolism [119]; this may explain why CHP was only effective in reducing cyclin D1 protein expression but not $\mathrm{pRb}$ and $\mathrm{pcdc} 2$ expression. 
SIRT1 is an important protein that plays a role in cell senescence. We hypothesized that both CHP and CHL could protect cell senescence by up-regulating SIRT1 expression. The Western blot results confirmed our hypothesis. When cells were treated with either CHP or CHL, SIRT1 expression was significantly up-regulated.

Furthermore, we hypothesized that SIRT1 would up-regulate through the phosphorylation of GAPDH. GAPDH and SIRT1 expression, when treated with either CHP or CHL, confirmed that both extracts could reduce the glucose level in cells. Figure $10 \mathrm{~b}$ showed the underlying mechanisms of both extracts. Low cellular glucose significantly increased the phosphorylation of GAPDH and SIRT1 expression. When cellular glucose decreased, GAPDH became a critical enzyme and was phosphorylated by AMP-activated protein kinase (AMPK), thus triggering SIRT1 activation. This process was necessary to protect cells from glucose starvation, such as autophagy and gluconeogenesis [120]. Results from the Western blot showed the association of SIRT1 and cyclin. These results are consistent previous studies, that is, down-regulated SIRT1 was arrested in the G1 phase via cyclin D1 signaling [121,122].

Thus, all results showed that both CHP and CHL could attenuate high glucose-induced cellular senescence in human neuronal SH-SY5Y cells by inducing the cell cycle progression and up-regulation of SIRT1.

In this study, we found $\mathrm{CH}$ extracts with high ROS-scavenging properties and they were able to protect high glucose-induced human neuronal senescence. The antioxidant and anti-senescent properties of $\mathrm{CH}$ extracts are also extensively discussed in further characterization from two perspectives.

\subsection{A Biochemical Perspective}

Notably, in this study, radical scavenging activity assays of CHP and CHL extracts dissolved in DMSO were performed with DPPH and ABTS in ethanol. However, it still needs to be established whether CHP and CHL extracts' radical scavenging activities could persist in living tissues' aqueous environment under physiological conditions. $\mathrm{CH}$ extracts should be administered to animals treated with high glucose to induce senescence. Followed by $\mathrm{CH}^{\prime}$ s biochemical evaluation on oxidative stress in blood and tissue samples should be investigated to clarify whether CHP and CHL have scavenging activities under physiological conditions. For example, using samples derived from blood or tissues, antioxidant biomarkers (such as Glutathione (GSH)) could be analyzed. The GSH content indicates the cell's defense against ROS causing cellular injury $[123,124]$ and reflecting the ability of a tissue to scavenge excess superoxide anions leading to oxidative stress [125], Malondialdehyde (MDA)-a direct indicator of cell membrane damage occurring in the tissue [126,127], Catalase (CAT)-an indicator of CH toleration by that particular tissue [128], Superoxide dismutase (SOD)-an indicator of the active enzyme involvement in neutralizing the effect of free radicals [129] and Level of protein content-an indicator of cell capacity of mitigating the effect of free radical and peroxide processes resulting in modulating the cellular antioxidant status [130]. Furthermore, other aspects, as below, are also concerned as described below [131,132].

- $\quad$ Therapeutic agents with high lipid solubility can penetrate cells more rapidly than therapeutic agents with water solubility. So, lipid or water solubility should be assessed.

- Most of the therapeutic agents are available as weak acids or weak bases. Thus the $\mathrm{pH}$ of therapeutic agents should be addressed appropriately.

- Oxidation-reduction potential (ORP) [133], also known as redox, should be determined because it reflects a molecule's ability to oxidize or reduce another molecule. Reducers have negative ORP and oxidizers have positive ORP. Typically, all organs in our body have negative OPR ( -10 to $-250 \mathrm{mV}$ of ORP). Oxidizers can oxidize another molecule, which causes it to lose electrons. Oxidizers become free radicals after accepting radicals and cause many diseases. On the other hand, free radicals can be neutralized with reducers and antioxidants, causing body improvement and rejuvenation. For medicinal benefits, $\mathrm{CH}$ or their major active constituents should have 
negative ORP and play a role as a reducer or antioxidant. Therefore, the proposed application of redox reactions is useful for $\mathrm{CH}$ determination in pharmaceuticals (Figure 11).

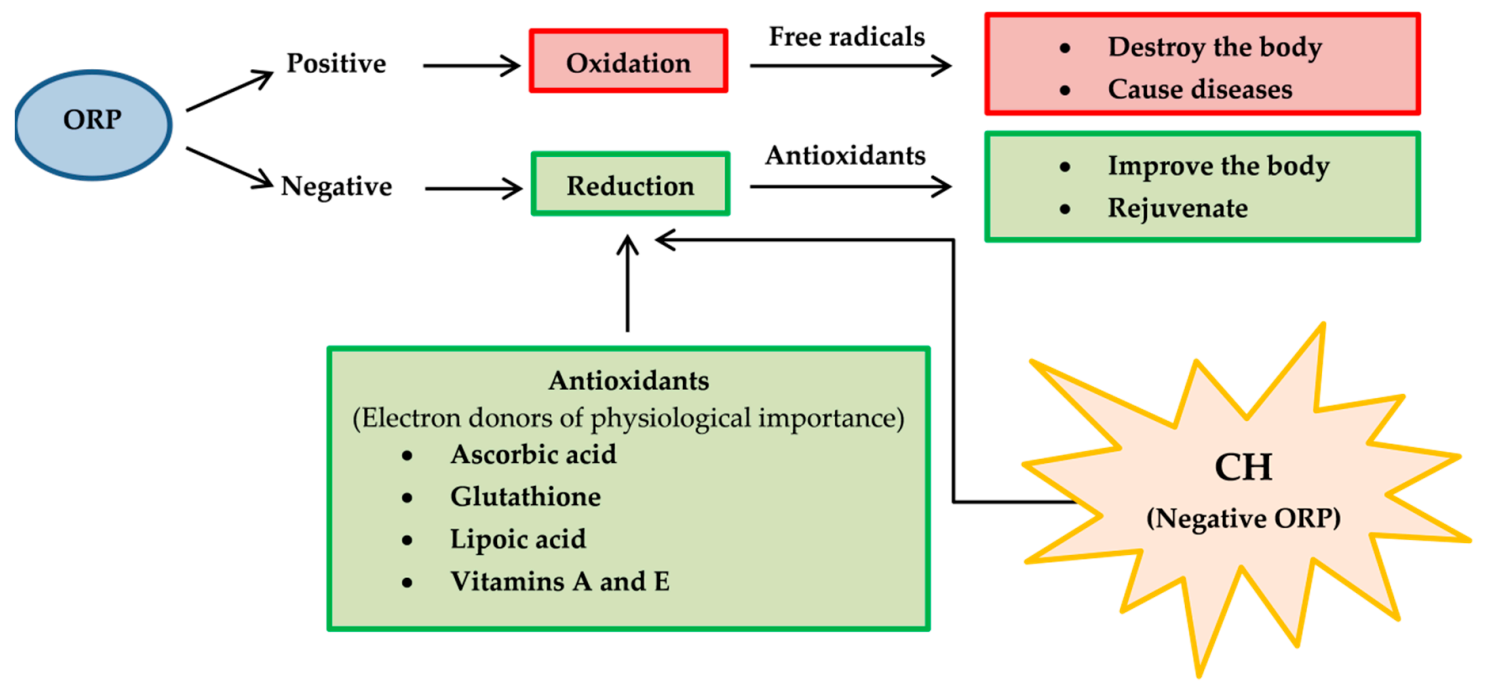

Figure 11. The potential applications of oxidation-reduction potential (ORP) or redox reaction for $\mathrm{CH}$ determination in pharmaceuticals.

- Oxygen partial pressure $\left(\mathrm{PO}_{2}\right)$ [134]: $\mathrm{PO}_{2}$ is the force exerted by oxygen. In the human body (highly aerobic organism), oxygen plays a role in energy production. Therefore, oxygen supply at the tissue must match metabolic demand. $\mathrm{PO}_{2}$ is useful to maintain homeostasis (the balance between oxygen delivery and its consumption) within organ and tissue. Each organ and tissue has its $\mathrm{PO}_{2}$ requirements in order to function correctly. $\mathrm{PO}_{2}$ is useful in predicting oxygen and oxygen movement will move from a higher $\mathrm{PO}_{2}$ area to a lower $\mathrm{PO}_{2}$ area. Typically, $\mathrm{PO}_{2}$ in tissue is low because oxygen is used in cellular respiration. When $\mathrm{PO}_{2}$ in tissue increased by several factors such as stress, anesthesia, tumor and diabetes, oxygen availability is low or hypoxia. In consideration of CH's pharmacology, the importance of hypoxia as below is concerned [135].

1. Hypoxia may alter the therapeutic effectiveness and metabolism of $\mathrm{CH}$.

2. Hypoxia may alter cellular function.

3. Hypoxia may potentiate or mitigate $\mathrm{CH}$-induced toxicity.

4. $\mathrm{CH}$ may potentiate or protect against hypoxia-induced pathology.

5. $\mathrm{CH}$ may alter the relative coupling of blood flow and energy metabolism in an organ.

\subsection{A Pharmacokinetic Perspective}

It is universally agreed before any novel bioactive compound considered a lead for developing an active principle of any preventive or therapeutic usefulness, it is essential to conduct exhaustive animal and pre-clinical studies. Therefore, pharmacokinetic evaluations of $\mathrm{CH}$ extracts' active phytochemicals should be studied in animal models including, blood samples for absorption studies, tissues such as intestine, liver, lungs, kidney and heart distribution studies and urine and excreta collection for excretion studies. After sample preparation, extraction of bioactive markers and assessment of pharmacokinetic parameters as listed below should be carried out [136]. The proposed pharmacokinetic diagram after administering the active phytochemical of $\mathrm{CH}$ extracts in an animal model is shown in Figure 12. 


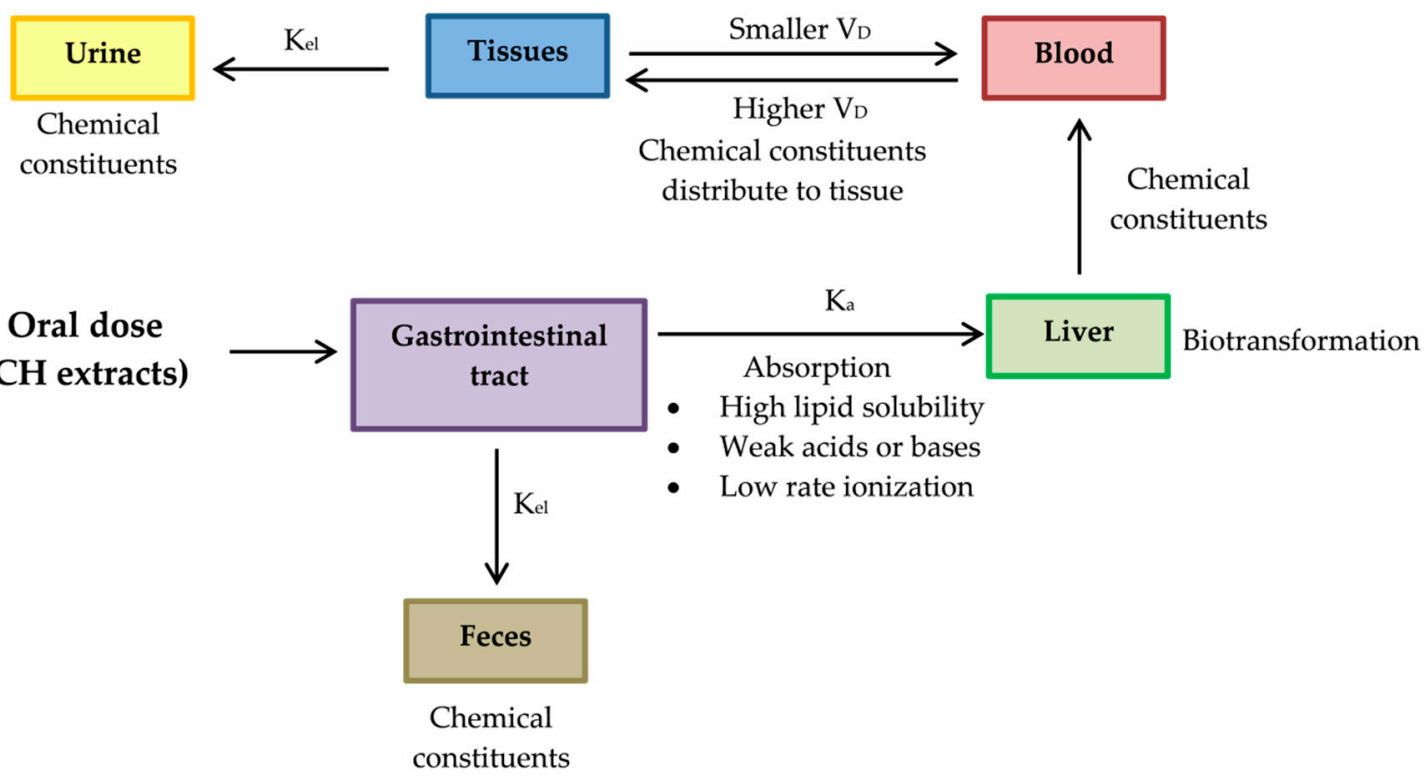

Figure 12. The proposed diagram of pharmacokinetics for evaluating of active phytochemicals of $\mathrm{CH}$ extracts. After chemical constituents are absorbed by gastrointestinal tract, they are delivered to liver, where they are biotransformed and delivered into blood. Chemical constituents are biodistributed to other peripheral organs by blood stream. Absorbed chemical constituents are excreted through the urine but certain chemical constituents that are not absorbed through the gastrointestinal tract will be eliminated through feces. Absorption rate constant $\left(K_{\mathrm{a}}\right)$; Constant elimination $\left(K_{\mathrm{el}}\right)$; Volume of distribution $\left(V_{\mathrm{D}}\right)$.

- Absorption rate constant $\left(K_{\mathrm{a}}\right)$ should be determined for a chemical compound of $\mathrm{CH}$. The compound investigated should have high $K_{\mathrm{a}}$, so its characteristics should be high lipid solubility, weak acids or weak bases and low rate ionization.

- Constant elimination $\left(K_{\mathrm{el}}\right)$ is a value that describes the rate at which an active compound of $\mathrm{CH}$ is removed from the human system. Its value is affected by all processes such as distribution, biotransformation and excretion.

- Volume of distribution $\left(V_{\mathrm{D}}\right)$ represents the distribution of a compound of $\mathrm{CH}$ in body tissues rather than the plasma. If $V_{\mathrm{D}}$ is higher than the total body water, it indicates a greater amount of tissue distribution. A smaller $V_{\mathrm{D}}$ means a compound remains in the plasma than $\mathrm{CH}$ distribution in tissues [137]. A compound studied for medicinal benefits should have higher $V_{\mathrm{D}}$, so it should be characterized by high lipid solubility, low rates of ionization and low plasma protein binding capabilities.

- Biotransformation represents the chemical alteration process of therapeutic agents in the body.

As far as pharmacokinetics is concerned, individual chemical constituents found in $\mathrm{CH}$ were previously studied, such as sitosterol [138] and caryophyllene [139].

\section{Materials and Methods}

\subsection{Chemicals and Reagents}

Dimethyl sulfoxide (DMSO) and ethanol were purchased from Merck (Darmstadt, Germany). Phenylmethyl sulphonyl fluoride (PMSF) was purchased from United States Biological (Cleveland, $\mathrm{OH}, \mathrm{USA}$ ). Kodak processing chemicals were used for autoradiography films. The Amersham ECL select Western blotting detection reagent was purchased from GE Healthcare (Piscataway, NJ, USA). Dulbecco's modified Eagle medium (DMEM)/low glucose, fetal bovine serum (FBS) and penicillin-streptomycin solution $(10,000 \mathrm{units} / \mathrm{mL}$ of penicillin and $10,000 \mu \mathrm{g} / \mathrm{mL}$ of streptomycin) were 
purchased from HyClone (Logan, UT, USA). A solution of 30\% acrylamide/bis-acrylamide (37.5:1) was purchased from Biorad (Hercules, CA, USA). Ammonium persulfate (APS) was purchased from EMD Millipore (Billerica, MA, USA). The monoclonal rabbit SIRT1 (D1D7, cat\#9475), GAPDH (14C10, cat\#2118), Cyclin D1 (92G2, cat\#2978), Phospho-Rb (Ser807/811, cat\#9308), Phospho-cdc2 (Tyr15, cat\#9111) and $\beta$ actin (13E5, cat\#4970) were purchased from Cell Signaling Technology (Beverly, MA, USA). Propidium iodide (PI) was purchased from Biolegend (San Diego, CA, USA).

\subsection{Plant Extraction}

Citrus hystrix (or kaffir lime) peels and leaves were designated as CHP and CHL, respectively and were cultivated in the Bang Ramat District, Taling Chan County and Bangkok, Thailand (Latitude, Longitude: 13.777883, 100.416748). They were harvested in October and November 2019. They were extracted by maceration method using 70\% ethanol (ratio $1: 5 w / v$ ) at room temperature (RT) in the dark for $48 \mathrm{~h}$ and filtered. The residue was extracted twice. The two filtrates were combined and concentrated by evaporation at $45^{\circ} \mathrm{C}$. The crude extracts were dissolved in DMSO or kept at $-80^{\circ} \mathrm{C}$ until further investigation.

\subsection{Gas Chromatograph-Mass Spectrometer (GC-MS) Analysis}

The extracts were submitted to the Scientific and Technological Research Equipment Center (STREC) (Chulalongkorn University, Thailand). The GC-MS Triple Quad system was an Agilent 7890 series GC system coupled with an Agilent 7000C MS and a capillary column (HP-5MS 5\% Phenyl Methyl Siloxane, length $30 \mathrm{~m}$, i.d. $0.25 \mathrm{~mm}$, phase thickness $0.25 \mu \mathrm{m})$. The GC was operated with helium as the carrier gas $(1 \mathrm{~mL} / \mathrm{min})$. The inlet had a temperature of $250{ }^{\circ} \mathrm{C}$, pressure set to $8.2317 \mathrm{psi}$ and $1.5 \mu \mathrm{L}$ injection. The GC oven was kept at $60^{\circ} \mathrm{C}$ for $3 \mathrm{~min}$ before rising to $325^{\circ} \mathrm{C}$ (with linear gradient of $\left.5{ }^{\circ} \mathrm{C} / \mathrm{min}\right)$ and kept at $325^{\circ} \mathrm{C}$ for $3 \mathrm{~min}$. The total run time was $14 \mathrm{~min}$. The extracts $(\sim 10 \mathrm{mg})$ were dissolved in $1 \mathrm{~mL}$ of absolute ethanol and their obtained spectra were compared with NIST Mass Spectrometry Data Center to identify phytochemical constituents.

\subsection{Antioxidant Determination}

\subsubsection{Folin-Ciocalteu Phenol Assay (FCP)}

The extracts $(50 \mu \mathrm{L})$ and $10 \%$ Folin-Ciocalteu Phenol reagent $(50 \mu \mathrm{L})$ were mixed and incubated in the dark at room temperature (RT) for $30 \mathrm{~min}$. A sodium carbonate $\left(\mathrm{Na}_{2} \mathrm{CO}_{3}\right)$ solution $(35 \mu \mathrm{L})$ was added, mixed and incubated in the dark at RT for $20 \mathrm{~min}$. Reaction absorbance was measured using the Enspire ${ }^{\circledR}$ Multimode Plate Reader (Perkin-Elmer) at $750 \mathrm{~nm}$. Gallic acid was used as the standard. The amount of phenolic compound was in a Gallic acid equivalent (GE) $\mathrm{mg} / \mathrm{g}$ of dry weight.

\subsubsection{Total Flavonoid of Determination}

The extracts $(50 \mu \mathrm{L})$ were mixed with the solution $(150 \mu \mathrm{L}$ of ethanol, $10 \mu \mathrm{L}$ of $1 \mathrm{M}$ Sodium acetate $(\mathrm{NaOAc})$ and $10 \mu \mathrm{L}$ of Aluminum Chloride $\left(\mathrm{AlCl}_{3}\right)$ ). The mixture was incubated in the dark at $\mathrm{RT}$ for $40 \mathrm{~min}$ and measured at $415 \mathrm{~nm}$. Quercetin was used as the standard. The content of flavonoid was in Quercetin equivalent (QE) mg/g of dry weight.

\subsubsection{Radical Scavenging Activity Assays}

Next, $0.2 \mathrm{mg} / \mathrm{mL}$ of 2,2-diphenyl-1-picryl-hydrazyl-hydrate $\left(\mathrm{DPPH}^{\bullet}\right)$ and freshly prepared 2,2'-azino-bis (3-ethylbenzthiazoline-6-sulphonic acid) $\left(\mathrm{ABTS}^{\bullet+}\right)\left(\mathrm{OD}_{734}=0.7-0.8\right)$ were diluted in ethanol. The extract $(1 \mathrm{mg} / \mathrm{mL})$ was reacted with $\mathrm{DPPH}^{\bullet}$ or $\mathrm{ABTS}^{\bullet+}$ and incubated at RT for 15 and $30 \mathrm{~min}$, respectively. Absorbance was measured at $517 \mathrm{~nm}$ and $734 \mathrm{~nm}$, respectively. Ascorbic acid (Vitamin C) was used as the standard for both assays. The antioxidant capacity had Vitamin C equivalent antioxidant capacity (VCEAC) in $\mathrm{mg} / \mathrm{g}$ of dry weight. 


\subsection{Cell Line}

SH-SY5Y cells-a human neuroblastoma cell line-were purchased from a cell line service (Heidelberg, Germany; Catalogue number 300154). They were cultured in DMEM/low glucose (HyClone, USA) containing 10\% FBS and antibiotics (100 U/mL penicillin and $100 \mu \mathrm{g} / \mathrm{mL}$ streptomycin) at $37^{\circ} \mathrm{C}$ in a humidified atmosphere at $5 \% \mathrm{CO}_{2}$.

\subsection{3-(4,5-Dimethylthiazol-2-yl)-2,5-diphenyltetrazolium bromide tetrazolium (MTT) Assay}

We determined the nontoxic concentration of CHP and CHL extracts with SH-SY5Y. Cells were seeded at 20,000 cells/well plates and incubated at $37^{\circ} \mathrm{C}$ for $24 \mathrm{~h}$. Cells were treated with various concentrations of extracts for $24 \mathrm{~h}$. MTT $(5 \mathrm{mg} / \mathrm{mL})$ was added to each well $(20 \mu \mathrm{L} /$ well $)$ and incubated for $4 \mathrm{~h}$. Media was removed carefully. In this step, a formazan product was formed and dissolved with $150 \mu \mathrm{l}$ of $100 \%$ DMSO. A supernatant was collected and transferred to a new 96-well plate. Moreover, it measured the absorbance with a spectrometer at $550 \mathrm{~nm}$. The nontoxic concentration of the extracts was shown as the percentage of cell viability calculated by the following formula.

$$
\% \text { cell viability }=\frac{\left(\mathrm{Abs}_{\text {treated cells }}-\mathrm{Abs}_{\text {blank }}\right) \times 100}{\mathrm{Abs}_{\text {untreated cells }}-\mathrm{Abs} \text { blank }}
$$

\subsection{Reactive Oxygen Species (ROS) Assay}

The appropriate concentration of extracts was tested. Cells were seeded at 20,000 cells/well in 96-well plates and incubated at $37^{\circ} \mathrm{C}$ for $24 \mathrm{~h}$. Cells were treated or co-treated with $100 \mathrm{mM}$ glucose or extracts for $24 \mathrm{~h}$. Next, $5 \mu \mathrm{M}$ of non-fluorescent $2^{\prime}, 7^{\prime}$-dichloro-dihydrofluorescein diacetate $\left(\mathrm{H}_{2}\right.$ DCFDA) was loaded, incubated at $37^{\circ} \mathrm{C}$ for $45 \mathrm{~min}$ and then washed 3 times with PBS. The level of intracellular ROS was measured based on the ability of ROS to oxidize non-fluorescent $\mathrm{H}_{2}$ DCFDA into a highly fluorescent $2^{\prime}, 7^{\prime}$-dichlorofluorescein (DCF). The fluorescence was measured with an excitation wavelength of $485 \mathrm{~nm}$ and an emission wavelength of $535 \mathrm{~nm}$.

\subsection{Cell Cycle Assay by Flow Cytometer}

Cells were seeded at 500,000 cells/well in 6-well plates and incubated at $37^{\circ} \mathrm{C}$ for $24 \mathrm{~h}$. Having been incubated, cells were co-treated with $100 \mathrm{mM}$ glucose and $1 \mu \mathrm{g} / \mathrm{mL}$ of CHP, CHL or gallic acid for $24 \mathrm{~h}$. After treatment, cells were harvested, washed in cold PBS and re-centrifuged at $400 \mathrm{~g}$ for $5 \mathrm{~min}$. Cells were re-suspended in absolute ethanol at $-20^{\circ} \mathrm{C}$ for at least $2 \mathrm{~h}$. Cells were washed and re-suspended in 1\% $(v / v)$ Triton X-100 PBS and treated with RNase. Next, $500 \mu \mathrm{L}$ of PI/Triton X-100 staining solution was added and incubated at $37^{\circ} \mathrm{C}$ for $15 \mathrm{~min}$. The cell cycle was analyzed via flow cytometry (FACSCalibur (BD Biosciences, San Jose, CA, USA)).

\subsection{Protein Expression by Western Blotting}

Cells were seeded at 500,000 cells/well in 6-well plates and incubated at $37^{\circ} \mathrm{C}$ for $24 \mathrm{~h}$. Cells were co-treated for $24 \mathrm{~h}$. The next day, protein extraction was carried out using $1 \mathrm{mM}$ of PMSF in a NP-40 lysis buffer. Total protein $(40 \mu \mathrm{g})$ was mixed with a $2 \times$ Laemmli buffer (ratio 1:1) and heated at $95^{\circ} \mathrm{C}$ for 10 min. Protein was separated with $10 \%$ sodium dodecyl sulfate-polyacrylamide gel electrophoresis (SDS-PAGE) and transferred onto polyvinylidene difluoride (PVDF) membranes. Membranes were blocked with $5 \%$ nonfat milk for $1 \mathrm{~h}$ at room temperature. Membranes were incubated with primary antibodies (cyclin D1 (1:2000), pRb (1:2000), pcdc2 (1:2000), SIRT 1 (1:2000), GAPDH $(1: 10,000)$ and $\beta$ actin $(1: 2000))$ overnight at $4{ }^{\circ} \mathrm{C}$. After incubation, membranes were washed 3 times with $1 \times$ TBS-Tween 20 (TBST) for $15 \mathrm{~min}$, incubated with secondary antibodies (anti-rabbit IgG, HRP-linked antibody) for $45 \mathrm{~min}$ at RT and washed 3 times with TBST for $15 \mathrm{~min}$. Protein bands were visualized by adding an enhanced chemiluminescence detection reagent using autoradiography films and Kodak processing chemicals. Each band was normalized against $\beta$ actin as an internal control. 


\subsection{Statistical Analysis}

Data were presented as the mean \pm standard deviation (SD). Means were from at least three independent experiments. Data were analyzed via a one-way analysis of variance (ANOVA) followed by a post hoc Tukey test $(p$ value $<0.05)$ using low glucose-treated cells as the control group.

\section{Conclusions}

In summary, our results demonstrate that $\mathrm{CH}$ is an interesting plant with rich antioxidant properties and bioactive compounds. Both CHP and CHL can protect human neuronal cells from glucose-induced neuronal senescence. The neuroprotective effect of $\mathrm{CHP}$ and $\mathrm{CHL}$ is mediated through cell cycle progression in cell cycle checkpoint proteins and SIRT1 up-regulation after SIRT1/GAPDH pathway activation. $\mathrm{CH}$ extracts could be developed as agents for the protection of high glucose-induced neuronal senescence.

However, the bioactivities of this extract needs to be further explored in other living organisms. Hopefully, neuronal senescence-associated diseases will be clarified in further investigations.

Author Contributions: N.P. designed and performed the experiments, analyzed and discussed the data and wrote the paper; T.T. conducted the critical revision and consulted the data. All authors have read and agreed to the published version of the manuscript.

Funding: This research was funded by the grant from Age-Related Inflammation and Degeneration Research Unit. This research project is supported by the Second Century Fund (C2F), Chulalongkorn University.

Acknowledgments: The authors would like to acknowledge the staff of Division of Allergy and Clinical Immunology, Faculty of Medicine, Chulalongkorn University for allowing the authors to access the flow cytometry facility and the staff of Scientific and Technological Research Equipment Centre (STREC), Chulalongkorn University to analyze phytochemical constituents by Gas Chromatograph-Mass Spectrometer. We would like to express our gratitude to James M. Brimson (Department of Clinical Chemistry, Faculty of Allied Health Sciences, Chulalongkorn University) for his help in English editing and proofreading.

Conflicts of Interest: The authors declare no conflict of interest.

\section{References}

1. Wu, L.; Chen, Y.; Wang, C.Y.; Tang, Y.Y.; Huang, H.L.; Kang, X.; Li, X.; Xie, Y.R.; Tang, X.Q. Hydrogen sulfide inhibits high glucose-induced neuronal senescence by improving autophagic flux via up-regulation of SIRT1. Front. Mol. Neurosci. 2019, 12,1-13. [CrossRef]

2. Fan, F.; Liu, T.; Wang, X.; Ren, D.; Liu, H.; Zhang, P.; Wang, Z.; Liu, N.; Li, Q.; Tu, Y.; et al. ClC-3 expression and its association with hyperglycemia induced HT22 hippocampal neuronal cell apoptosis. J. Diabetes Res. 2016, 2016, 1-12. [CrossRef]

3. Sima, A.A.; Kamiya, H.; Li, Z.G. Insulin, C-peptide, hyperglycemia, and central nervous system complications in diabetes. Eur. J. Pharmacol. 2004, 490, 187-197. [CrossRef]

4. Reno, C.M.; Tanoli, T.; Bree, A.; Daphna-Iken, R.; Cui, C.; Maloney, S.E.; Wozniak, D.F.; Fisher, S.J. Antecedent glycemic control reduces severe hypoglycemia-induced neuronal damage in diabetic rats. Am. J. Physiol. Metab. 2013, 304, 1331-1337. [CrossRef] [PubMed]

5. Lee, H.J.; Seo, H.I.; Cha, H.Y.; Yang, Y.J.; Kwon, S.H.; Yang, S.J. Diabetes and Alzheimer's Disease: Mechanisms and Nutritional Aspects. Clin. Nutr. Res. 2018, 7, 229-240. [CrossRef] [PubMed]

6. Mao, Z.; Ke, Z.; Gorbunova, V.; Seluanov, A. Replicatively senescent cells are arrested in G1 and G2 phases. Aging 2012, 4, 431-435. [CrossRef]

7. Stein, G.H.; Dulic, V. Origins of G1 arrest in senescent human fibroblasts. BioEssays 1995, 17, $537-543$. [CrossRef] [PubMed]

8. Giacinti, C.; Giordano, A. RB and cell cycle progress. Oncogene 2006, 25, 5220-5227. [CrossRef] [PubMed]

9. Brown, V.D.; Phillips, R.A.; Gallie, B.L. Cumulative Effect of Phosphorylation of pRB on Regulation of E2F Activity. Mol. Cell. Boil. 1999, 19, 3246-3256. [CrossRef]

10. Draetta, G.; Luca, F.; Westendorf, J.; Brizuela, L.; Ruderman, J.; Beach, D. Cdc2 protein kinases complexed with both cyclin A and B: Vidence for proteolytic inactivation of MPF. Cell 1989, 56, 829-838. [CrossRef] 
11. Yang, K.; Hitomi, M.; Stacey, D.W. Variations in cyclin D1 levels through the cell cycle determine the proliferative fate of cell. Cell Div. 2006, 1, 32. [CrossRef] [PubMed]

12. Rezaei, P.F.; Fouladdel, S.; Ghaffari, S.M.; Amin, G.; Azizi, E. Induction of G1 cell cycle arrest and cyclin D1 down-regulation in response to pericarp extract of Baneh in human breast cancer T47D cells. DARU J. Pharm. Sci. 2012, 20, 101. [CrossRef] [PubMed]

13. Masamha, C.P.; Benbrook, D.M. Cyclin D1 degradation is sufficient to induce G1 cell cycle arrest despite constitutive expression of cyclin E2 in ovarian cancer cells. Cancer Res. 2009, 69, 6565-6572. [CrossRef] [PubMed]

14. Baldin, V.; Lukas, J.; Marcote, M.J.; Pagano, M.; Draetta, G. Cyclin D1 is a nuclear protein required for cell cycle progression in G1. Genes Dev. 1993, 7, 812-821. [CrossRef] [PubMed]

15. Lee, S.H.; Lee, J.H.; Lee, H.Y.; Min, K.J. Surtuin signaling in cellular senescence and aging. BMB Rep. 2019, 52, 24-34. [CrossRef] [PubMed]

16. Lamichane, S.; Baek, S.H.; Kim, Y.J.; Park, J.H.; Lamichane, B.D.; Jang, W.B.; Ji, S.T.; Lee, N.K.; Dehua, L.; Kim, D.Y.; et al. MHY2233 attenuates replicative cellular senescence in human endothelial progenitor cells via SIRT1 signaling. Oxidative Med. Cell. Longev. 2019. [CrossRef]

17. Wang, Y.; Liang, Y.; Vanhoutte, P.M. SIRT1 and AMPK in regulating mammalian senescence: A critical review and a working model. FEBS Lett. 2010, 585, 986-994. [CrossRef]

18. Liu, T.F.; McCall, C.E. Deacetylation by SIRT1 reprograms inflammation and cancer. Genes Cancer 2013, 4, 135-147. [CrossRef]

19. Hutadilok-Towatana, N.; Chaiyamutti, P.; Panthong, K.; Mahabusarakam, W.; Rukachaisirikul, V. Antioxidative and Free Radical Scavenging Activities of Some Plants Used in Thai Folk Medicine. Pharm. Biol. 2006, 44, 221-228. [CrossRef]

20. Abirami, A.; Nagarami, G.; Siddhuraju, P. The medicinal and nutritional role of underutilized citrus fruit Citrus hystrix (Kaffir lime): A review. Drug Invent. Today 2014, 6, 1-5.

21. Irawaty, W.; Ayucitra, A. Assessment on antioxidant and in vitro antidiabetes activities of different fractions of Citrus hystrix peel. Int. Food Res. J. 2018, 6, 2467-2477.

22. Abirami, A.; Nagarami, G.; Siddhuraju, P. In vitro antioxidant, anti-diabetic, cholinesterase and tyrosinase inhibitory potential of fresh juice from Citrus hystrix and C. maxima fruits. Food Sci. Hum. Wellness 2014, 3 , 16-25. [CrossRef]

23. Abirami, A.; Nagarami, G.; Siddhuraju, P. Hepatoprotective of leaf extracts from Citrus hystrix and C. maxima against paracetamol induced liver injury in rat. Food Sci. Hum. Wellness 2015, 4, 35-41. [CrossRef]

24. Taweechaisupapong, S.; Aromdee, C.; Khunkitti, W. Antibacterial activity of citronella oil solid lipid particles in oleogel against Propionibacterium acnes and itschemical stability. Int. J. Essent. Oil Ther. 2008, 2, 167-171.

25. Pattnaik, S.; Vemulpad, S.; Kole, C. Antibacterial and Antifungal activity of ten essential oils in vitro. Microbios 1996, 86, 237-246. [PubMed]

26. Jantamas, S.; Matan, N.; Aewsiri, T. Improvement of antifungal activity of Citronella oil against Aspergillus flavus on rubberwood (Hevea Brasiliensis) using heat curing. J. Trop. For. Sci. 2016, 28, 39-47.

27. Kandimalla, R.; Kalita, S.; Choudhury, B.; Dash, S.; Kalita, K.; Kotoky, J. Chemical Composition and Anti-Candidiasis Mediated Wound Healing Property of Cymbopogon nardus Essential Oil on Chronic Diabetic Wounds. Front. Pharmacol. 2016, 7, 1-8.

28. Batubara, I.; Suparto, I.H.; Sa'diah, S.; Matsuoka, R.; Mitsunaga, T. Effects of Inhaled Citronella oil and Related Compounds on Rat Body Weight and Brown Adipose Tissue Sympathetic Nerve. Nutrients 2015, 7, 1859-1870. [CrossRef]

29. Wasito, W.; Noorhamdani, N.; Sukardi, S.; Suratmo, S. Assessment of antioxidant activity of citronellal extract and fractions of essential oils of Citrus hystrix DC. Trop. J. Pharm. Res. 2018, 17, 1119-1125. [CrossRef]

30. Santos, P.L.; Matos, J.P.S.C.F.; Picot, L.; Almeida, J.R.G.S.; Quintans, J.S.S.; Quintans-Junior, L.J. Citronellol, a monoterpene alcohol with promising pharmacological activities-A systematic review. Food Chem. Toxicol. 2018, 123, 459-469. [CrossRef]

31. De Sousa, D.P.; Goncalves, J.C.R.; Quintans-Junior, L.; Cruz, J.S.; Araujo, D.A.M.; de Almeida, R.N. Study of anticonvulsant effect of citronellol, a monoterpene alcohol, in rodents. Neurosci. Lett. 2006, 401, 231-235. [CrossRef] [PubMed] 
32. Bastos, J.F.; Moreira, I.J.; Ribeiro, T.P.; Medeiros, I.A.; Antoniolli, A.R.; de Sousa, D.P.; Santos, M.R. Hypotensive and vasorelaxant effects of citronellol, a monoterpene alcohol, in rats. Basic Clin. Pharmacol. Toxicol. 2009, 106, 331-337. [CrossRef] [PubMed]

33. Varga, Z.V.; Matyas, C.; Erdelyi, K.; Cinar, R.; Nieri, D.; Chicca, A.; Nemeth, B.T.; Paloczi, J.; Lajtos, T.; Corey, L.; et al. $\beta$-Caryophyllene protects against alcoholic steatohepatitis by attenuating inflammation and metabolic dysregulation in mice. Br. J. Pharmacol. 2018, 175, 320-334. [CrossRef] [PubMed]

34. Medeiros, R.; Passos, G.F.; Vitor, C.E.; Koepp, J.; Mazzuco, T.L.; Pianowski, L.F.; Campos, M.M.; Calixto, J.B. Effect of two active compounds obtained from the essential oil of Cordia verbenacea on the acute inflammatory responses elicited by LPS in the rat paw. Br. J. Pharmacol. 2007, 151, 618-627. [CrossRef]

35. Ojha, S.; Javed, H.; Azimullah, S.; Haque, M.E. Beta-Caryophyllene, a phytocannabinoid attenuates oxidative stress, neuroinflammation, glial activation, and salvages dopaminergic neurons in a rat model of Parkinson disease. Mol. Cell. Biochem. 2016, 418, 59-70. [CrossRef] [PubMed]

36. Neto, J.N.; de Almeida, A.; da Silva Oliveira, J.; dos Santos, P.; de Sousa, D.; de Freitas, R. Antioxidant effects of nerolidol in mice hippocampus after open field test. Neurochem. Res. 2013, 38, 1861-1870. [CrossRef]

37. Hada, T.; Shiraishi, A.; Furuse, S.; Inoue, Y.; Hamashima, H.; Matsumoto, Y.; Masuda, K.; Shiojima, K.; Shimada, J. Inhibitory effects of terpenes on the growth of Staphylococcus aureus. Nat. Med. 2003, 57, $64-67$.

38. Lee, K.; Lee, J.H.; Kim, S.I.; Cho, M.; Lee, J. Anti-biofilm, anti-hemolysis, and anti-virulence activities of black pepper, cananga, myrrh oils, and nerolidol against Staphylococcus aureus. Appl. Microbiol. Biotechnol. 2014, 98, 9447-9457. [CrossRef]

39. Curvelo, J.A.R.; Marques, A.M.; Barreto, A.L.S.; Romanos, M.T.V.; Portela, M.B.; Kaplan, M.A.C.; Soares, R.M.A. A novel nerolidol-rich essential oil from Piper claussenianum modulates Candida albicans biofilm. J. Med. Microbiol. 2014, 63, 697-702. [CrossRef]

40. Park, M.J.; Gwak, K.S.; Yang, I.; Kim, K.W.; Jeung, E.B.; Chang, J.W.; Choi, I.G. Effect of citral, eugenol, nerolidol and $\alpha$-terpineol on the ultrastructural changes of Trichophyton mentagrophytes. Fitoterapia 2009, 80, 290-296. [CrossRef]

41. Renan, O.S.; Sousa, F.B.M.; Damasceno, S.R.B.; Carvalho, N.S.; Silva, V.G.; Oliviera, F.R.; Sousa, D.P.; Aragao, K.S.; Barbosa, A.L.R.; Freitas, R.M.; et al. Phytol, a diterpene alcohol, inhibits the inflammatory response by reducing cytokine production and oxidative stress. Fundam. Clin. Pharmacol. 2014, 4, 455-464.

42. Saeed, N.M.; El-Demerdash, E.; Abdel-Rahman, H.M.; Algandaby, M.M. Anti-inflammatory activity of methyl palmitate and ethyl palmitate in different experimental rat models. Toxicol. Appl. Pharmacol. 2012, 264, 84-93. [CrossRef]

43. Plat, J.; Mensink, R.P. Effects of plant sterols and stanols on lipid metabolism and cardiovascular risk. Nutr. Metab. Cardiovasc. Dis. 2001, 11, 31-40.

44. Gylling, H.; Plat, J.; Turley, S.; Ginsberg, H.N.; Ellegård, L.; Jessup, W.; Jones, P.J.; Lütjohann, D.; Maerz, W.; Masana, L.; et al. Plant sterols and plant stanols in the management of dyslipidaemia and prevention of cardiovascular disease. Atherosclerosis 2014, 232, 346-360. [CrossRef] [PubMed]

45. Ayaz, M.; Junaid, M.; Ullah, F.; Subhan, F.; Sadiq, A.; Ali, G.; Ovais, M.; Shahid, M.; Ahmad, A.; Wadood, A.; et al. Anti-Alzheimer's Studies on $\beta$-Sitosterol Isolated from Polygonum hydropiper L. Front. Pharmacol. 2017, 8. [CrossRef] [PubMed]

46. He, C.; Li, W.; Zhang, J.J.; Qu, S.S.; Wang, L.Y. Determination of $\beta$-Sitosterol and Total Sterols Content and Antioxidant Activity of Oil in Acai (Euterpe Oleracea). China J. Chin. Mater. Med. 2014, 39, 4620-4624.

47. Yoshida, Y.; Niki, E. Antioxidant effects of phytosterol and its components. J. Nutr. Sci. Vitaminol. 2003, 49, 277-280. [CrossRef]

48. Brimson, J.M.; Brimson, S.J.; Brimson, C.A.; Rakkhitawatthana, V.; Tencomnao, T. Rhinacanthus nasutus extracts prevent glutamate and amyloid- $\beta$ neurotoxicity in HT-22 mouse hippocampal cells: Possible active compounds include lupeol, stigmasterol and $\beta$-sitosterol. Int J. Mol. Sci. 2012, 13, 5074-5097. [CrossRef]

49. Sabino, C.K.; Ferreria-Filho, E.S.; Mendes, M.B.; Da SilvaFilho, J.C. Cardiovascular effects induced by $\alpha$-terpineol in hypertensive rats. Flavour Frag. J. 2013, 28, 333-339. [CrossRef]

50. Adorjan, B.; Buchbauer, G. Biological properties of essential oils: An update review. Flavour Frag. J. 2010, 25, 407-426. [CrossRef]

51. Khaleel, C.; Tabanca, N.; Buchbauer, G. $\alpha$-Terpineol, a natural monoterpene: A review of its biological properties. Open Chem. 2018, 16, 349-361. 
52. De Sousa, G.M.; Cazarin, C.B.B.; Junior, M.R.M.; Lamas, C.A.; Quitete, V.H.A.C.; Pastore, G.M.; Bicas, J.L. The effect of $\alpha$-terpineol enantiomers on biomarkers of rats fed a high-fat diet. Heliyon 2020, 6, e03752. [CrossRef]

53. Srisukh, V.; Tribuddharat, C.; Nukoolkarn, V.; Bunyapraphatsara, N.; Chokephaibulkit, K.; Phoomniyom, S.; Chaunphung, S.; Srifuengfung, S. Antibacterial activity of essential oils from Citrus hystrix (makrut lime) against respiratory tract pathogens. Science 2012, 38, 212-217.

54. Chaikul, P.; Khat-Udomkiri, N.; Iangthanarat, K.; Manosroi, J.; Manosroi, A. Characteristics and in vitro anti-skin aging activity of gallic acid loaded in cationic CTAB noisome. Eur. J. Pharm. Sci. 2019, 131, $39-49$. [CrossRef] [PubMed]

55. Hwang, E.; Park, S.Y.; Lee, H.J.; Lee, T.Y.; Sun, Z.W.; Yi, T.H. Gallic acid regulates skin photoaging in UVB-exposed fibroblasts and hairless mice. Phytother. Res. 2014, 28, 1778-1788. [PubMed]

56. Li, L.; Ng, T.B.; Gao, W.; Li, W.; Fu, M.; Niu, S.M.; Zhao, L.; Chen, R.R.; Liu, F. Antioxidant activity of gallic acid from rose flowers in senescence accelerated mice. Life Sci. 2005, 77, 230-240.

57. Hajipour, S.; Sarkaki, A.; Farbood, Y.; Eidi, A.; Mortazavi, P.; Valizadeh, Z. Effect of gallic acid on dementia type of Alzheimer disease in rats: Electrophysiological and Histological studies. Basic Clin. Neurosci. 2015, 7, 97-106.

58. Patel, S.S.; Goyal, R.K. Cardioprotective effects of gallic acid indiabetes-induced myocardial dysfunction in rats. Pharmacogn. Res. 2011, 3, 239-245.

59. Elahi, E.; Ashfaq, A.; Mustafa, S. Impact of gallic acid on oxidative stress in diabetes. PJMHS 2018, 12, 80-82.

60. Shabani, S.; Rabiei, Z.; Amini-Khoei, H. Exploring the multifaceted neuroprotective actions of gallic acid: A review. Int. J. Food Prop. 2020, 23, 736-752.

61. Saeki, Y.; Shiohara, M. Physiological effects of inhaling fragnances. Int. J. Aromather. 2001, 11, 118-125. [CrossRef]

62. Sayowan, W.; Siripornpanich, V.; Piriyapunyaporn, T.; Hongratanaworakit, T.; Kotchabhakdi, N.; Ruangrungsi, N. The Harmonizing Effects of Citronella Oil on Mood States and Brain Activities. J. Health Res. 2012, 26, 69-75.

63. Brito, R.G.; Guimaraes, A.G.; Quintans, J.S.; Santos, M.R.V.; De Sousa, D.P.; Badaue-Passos, D., Jr.; de Lucca, W., Jr.; Brito, F.A.; Barreto, E.O.; Oliviera, A.P.; et al. Citronellol, a monoterpene alcohol, reduces nociceptive and inflammatory activites in rodents. J. Nat. Med. 2012, 66, 637-644. [CrossRef] [PubMed]

64. Drapeau, J.; Rossano, M.; Touraud, D.; Obermayr, U.; Geier, M.; Rose, A.; Kunz, W. Green synthesis of para-Menthan-3,8-diol from Eucalyptus citriodora: Application for repellent products. C. R. Chim. 2011, 14, 629-635. [CrossRef]

65. Carroll, S.P.; Loye, J. PMD, a Registered Botanical Mosquito Repellent with Deet-Like Efficacy. J. Am. Mosq. Control Assoc. 2006, 22, 507-514. [CrossRef]

66. Chang, H.J.; Kim, J.M.; Lee, J.C.; Kim, W.K.; Chun, H.S. Protective effect of beta-caryophyllene, a natural bicyclic sesquiterpene, against cerebral ischemic injury. J. Med. Food 2013, 16, 471-480. [CrossRef]

67. Viveros-Paredes, J.M.; Gonzalez-Castaneda, R.E.; Gertsch, J.; Chaparro-Huerta, V.; Lopez-Roa, R.I.; Vazquez-Valls, E.; Beas-Zarate, C.; Camins-Espuny, A.; Flores-Soto, M.E. Neuroprotective Effects of beta-Caryophyllene against Dopaminergic Neuron Injury in a Murine Model of Parkinson's disease Induced by MPTP. Pharmaceuticals 2017, 10, 60. [CrossRef]

68. Assis, L.C.; Straliotto, M.R.; Engel, D.; Hort, M.A.; Dutra, R.C.; de Bem, A.F. Beta-Caryophyllene protects the C6 glioma cells against glutamate-induced excitotoxicity through the Nrf2 pathway. Neuroscience 2014, 279, 220-231. [CrossRef]

69. Youssef, D.A.; El-Fayoumi, H.M.; Mahmoud, M.F. Beta-caryophyllene protects against diet-induced dyslipidemia and vascular inflammation in rats: Involvement of CB2 and PPAR-gamma receptors. Chem. Biol. Interact. 2019, 297, 16-24. [CrossRef]

70. Katsuyama, S.; Mizoguchi, H.; Kuwahata, H.; Komatsu, T.; Nagaoka, K.; Nakamura, H.; Bagetta, G.; Sakurada, T.; Sakurada, S. Involvement of peripheral cannabinoid and opioid receptors in beta-caryophyllene-induced antinociception. Eur. J. Pain 2013, 17, 664-675. [CrossRef]

71. Alberti, T.B.; Barbosa, W.L.; Vieira, J.L.; Raposo, N.R.; Dutra, R.C. (-)-beta-Caryophyllene, a CB2 Receptor-Selective Phytocannabinoid, Suppresses Motor Paralysis and Neuroinflammation in a Murine Model of Multiple Sclerosis. Int. J. Mol. Sci. 2017, 18, 691. [CrossRef] [PubMed] 
72. Yoon, M.A.; Jeong, T.S.; Park, D.S.; Xu, M.Z.; Oh, H.W.; Song, K.B.; Lee, W.S.; Park, H.Y. Antioxidant effects of quinolone alkaloids and 2,4-di-tert-butylphenol isolated from Scolopendra subspinipes. Biol. Pharm. Bull. 2006, 29, 735-739. [CrossRef] [PubMed]

73. Choi, S.J.; Kim, J.K.; Kim, H.K.; Harris, K.; Kim, C.J.; Park, G.G.; Park, C.S.; Shin, D.H. 2,4-Di-tert-butylphenol from potato protects against oxidative stress in PC12 cells and mice. J. Med. Food 2013, 16, 977-983. [CrossRef] [PubMed]

74. Nair, R.V.R.; Jayasree, D.V.; Biju, P.G.; Baby, S. Anti-inflammatory and anticancer activities of erythrodiol-3-acetate and 2,4-di-tert-butylphenol isolated from Humboldtia unijuga. Nat. Prod. Res. 2018, 26, 1-4. [CrossRef] [PubMed]

75. Zhao, F.; Wang, P.; Lucardi, R.D.; Su, Z.; Li, S. Natural Sources and Bioactivities of 2,4-Di-Tert-Butyphenol and Its Analogs. Toxins 2019, 12, 35. [CrossRef]

76. Lushchak, V.I. Free radicals, reactive oxygen species, oxidative stress and its classification. Chem. Biol. Interact. 2014, 224, 164-175. [CrossRef]

77. Rahman, K. Studies on free radicals, antioxidants, and co-factors. Clin. Interv. Aging 2007, 2, $219-236$.

78. Uttara, B.; Singh, A.V.; Zamboni, P.; Mahajan, R.T. Oxidative stress and neurodegenerative diseases: A review of upstream and downstream antioxidant therapeutic options. Curr. Neuropharmacol. 2009, 7, 65-74. [CrossRef]

79. Halliwell, B. Antioxidants in human health and disease. Annu. Rev. Nutr. 1996, 16, 33-50. [CrossRef]

80. Wang, C.Y.; Wang, S.Y.; Chen, C.T. Increasing antioxidant activity and reducing decay of blueberries by essential oils. J. Agric. Food Chem. 2008, 56, 3587-3592. [CrossRef]

81. Pinheiro, B.G.; Silva, A.S.B.; Souza, G.E.P.; Figueiredo, J.G.; Cunha, F.Q.; Lahlou, S.; da Silva, J.K.R.; Maia, J.G.S.; Sousa, P.J.C. Chemical composition, antinociceptive and anti-inflammatory effects in rodents of the essential oil of Peperomia serpens (SW.) Loud. J. Ethnopharmacol. 2011, 138, 479-486. [CrossRef] [PubMed]

82. Fonsêca, D.V.; Salgado, P.R.R.; de Carvalho, F.L.; Salvadori, M.G.S.S.; Penha, A.R.S.; Leite, F.C.; Borges, C.J.S.; Piuvezam, M.R.; Pordeus, L.C.d.M.; Sousa, D.P.; et al. Nerolidol exhibits antinociceptive and anti-inflammatory activity: Involvement of the GABAergic system and proinflammatory cytokines. Fundam. Clin. Pharmacol. 2015, 30, 14-22. [CrossRef] [PubMed]

83. Arbale, V.A.; Kamble, G.S.; Khatiwora, E.; Ghayal, N. Antioxidant capacity of leaves and stem of Ehretia laevis. Int. J. Pharm. 2011, 3, 149-151.

84. Tyagi, T.; Agarwal, M. Phytochemical screening and GC-MS analysis of bioactive constituents in the ethanolic extract of Pistia stratiotes L. and Eichhornia crassipes (mart.) solms. J. Pharmacogn. Phytochem. 2017, 6, 195-206.

85. Syad, N.A.; Rajamohamed, B.S.; Shunmugaiah, K.P.; Kasi, P.D. Neuroprotective Effect of the Marine Macroalga Gelidiella Acerosa: Identification of Active Compounds Through Bioactivity-Guided Fractionation. Pharm Biol. 2016, 54, 2073-2081. [CrossRef]

86. García-Argáez, A.N.; Apan, T.O.R.; Delgado, H.P.; Velázquez, G.; Martínez-Vázquez, M. Anti-inflammatory Activity of Coumarins from Decatropis Bicolor on TPA Ear Mice Model. Planta Med. 2000, 66, 279-281. [CrossRef]

87. Zahri, S.; Razavi, S.M.; Moatamed, Z. Antioxidant activity and cytotoxic effect of aviprin and aviprin-3"-O-D-glucopyranoside on LNCaP and HeLa cell lines. Nat. Prod. Res. 2012, 26, 540-547. [CrossRef]

88. Kang, T.J.; Lee, S.Y.; Singh, R.P.; Agarwal, R.; Yim, D.S. Anti-tumor activity of oxypeucedanin from Ostericum koreanum against human prostate carcinoma DU145 cells. Acta Oncol. 2009, 48, 895-900. [CrossRef]

89. Altameme, H.J.; Hameed, I.H.; Idan, S.A. Artemisia annua: Biochemical products analysis of methanolic aerial parts extract and anti-microbial capacity. RJPBCS 2016, 7, 1843-1868.

90. Costa, E.V.; Dutra, L.M.; De Jesus, H.C.R.; Nogueira, P.C.D.L.; Moraes, V.R.D.S.; Salvador, M.J.; Cavalcanti, S.C.D.H.; Santos, R.L.C.D.; Prata, A.P.D.N. Chemical composition and antioxidant, antimicrobial, and larvicidal activities of the essential oils of Annona salzmannii and A. pickelii (Annonaceae). Nat. Prod. Commun. 2011, 6, 907-912. [CrossRef]

91. Turkez, H.; Togar, B.; Tatar, A.; Geyikoglu, F. Cytotoxic and cytogenetic effects of $\alpha$-copaene on rat neuron and N2a neuroblastoma cell lines. Biologia 2014, 69, 936-942. [CrossRef]

92. Kundu, A.; Saha, S.; Walia, S.; Ahluwalia, V.; Kaur, C. Antioxidant potential of essential oil and cadinene sesquiterpenes of Eupatorium adenophorum. Toxicol. Environ. Chem. 2013, 95, 127-137. [CrossRef] 
93. Ramesh, B.; Pugalendi, K.V. Antihyperlipidemic and antidiabetic effects of umbelliferone in streptozotocin diabetic rats. Yale J. Biol. Med. 2005, 78, 189-196.

94. Ramu, R.; Shirahatti, P.S.; Nanjunda, S.S.; Zameer, F.; Dhananjaya, B.L.; Nagendra, P.M.N. Correction: Assessment of In vivo Antidiabetic Properties of Umbelliferone and Lupeol Constituents of Banana (Musa sp. Var. Nanjangud Rasa Bale) Flower in Hyperglycaemic Rodent Model. PLoS ONE 2016, 11, e0151135. [CrossRef] [PubMed]

95. Sim, M.O.; Lee, H.I.; Ham, R.; Seo, K.I.; Kim, M.J.; Lee, M.K. Anti-inflammatory and antioxidant effects of umbelliferone in chronic alcohol-fed rats. Nutr. Res. Pract. 2015, 9, 364-369. [CrossRef]

96. Sigh, R.; Sigh, B.; Sigh, S.; Kumar, N. Umbelliferone-An antioxidant isolated from Acacia nilotica (L.) Willd. Ex. Del. Food Chem. 2009, 120, 825-830.

97. Seong, S.H.; Ali, M.Y.; Jung, H.A.; Choi, J.S. Umbelliferone derivatives exert neuroprotective effects by inhibiting monoamine oxidase A, self-amyloid $\beta$ aggregation, and lipid peroxidation. Bioorganic Chem. 2019, 92, 103293. [CrossRef]

98. Subramaniam, S.R.; Ellis, E.M. Neuroprotective effects of umbelliferone and esculetin in a mouse model of Parkinson's disease. J. Neurosci. Res. 2013, 91, 453-461. [CrossRef]

99. Liang, S.; Chen, Z.; Li, H.; Cang, Z.; Yin, K.; Wu, M.; Luo, S. Neuroprotective effect of Umbelliferone against Cerebral ischemia/Reperfusion induced neurological deficits: In-vivo and in-silico studies. J. Biomol. Struct. Dyn. 2020. [CrossRef]

100. Qakmak, Y.S.; Aktumsek, A.; Duran, A. Studies on antioxidant activity, volatile compound and fatty acid composition of different parts of Glycyrrhiza echinata L. EXCLI J. 2012, 11, 178-187.

101. Ng, T.B.; Liu, F.; Wang, Z.T. Antioxidative Activity of Natural Products from Plants. Life Sci. 2000, 66, 709-723. [PubMed]

102. He, W.; Chen, W.; Zhou, Y.; Tian, Y.; Liao, F. Xanthotoxol exerts neuroprotective effect via suppression of the inflammatory response in a rat model of focal cerebral ischemia. Cell Mol. Neurobiol. 2013, 33, 715-722. [PubMed]

103. Shalaby, N.M.M.; Abd-Alla, H.I.; Aly, H.F.; Albalawy, M.A.; Shaker, K.H.; Bouajila, J. Preliminary In Vitro and In Vivo Evaluation of Antidiabetic Activity of Ducrosia anethifolia boiss. and Its Linear Furanocoumarins. BioMed Res. Int. 2014. [CrossRef]

104. Doungsaard, P.; Chansakaow, S.; Sirithunyalug, J.; Shang-Chian, L.; Wei-Chao, L.; Chia-Hua, L.; Kuan-Ha, L.; Leelapornpisid, P. In vitro Biological Activities of the Anti-aging Potential of Dimocarpus longan Leaf Extracts. CMU J. Nat. Sci. 2020, 19, 235-251.

105. Cascale, H.S.; Mullers, E.; Lindqvist, A. How the cell cycle enforce senescence. Aging 2017, 9, 2022-2023.

106. Mombach, J.C.M.; Bug, C.A.; Chaouiya, C. Modelling the onset of senescence at the G1/S cell cycle checkpoint. BMC Genom. 2014, 15, 1-11.

107. Gire, V.; Dulic', V. Senecence from G2 arrest, revisited. Cell Cycle 2014, 14, 297-304.

108. Zhu, Y.; Armstrong, J.L.; Tchkonia, T.; Kirkland, J.L. Cellular senescence and the senescent secretory phenotype in age-related chronic diseases. Curr. Opin. Clin. 2014, 17, 324-328.

109. Campisi, J. Cancer, Aging and Cellular Senescence. In Vivo 2000, 14, 183-188. [PubMed]

110. Kumar, M.; Seeger, W.; Voswinckel, R. Senescence-associated Secretory Phenotype and Its Possicle Role in Chronic Obstructive Pulmonary Disease. Am. J. Respir. Cell Mol. Biol. 2014, 51, 323-333. [PubMed]

111. Minamino, T.; Miyauchi, H.; Yoshida, T.; Tateno, K.; Kunieda, T.; Komuro, I. Vascular Cell Senescence and Vascular Aging. J. Mol. Cell Cardiol. 2004, 36, 175-183. [CrossRef] [PubMed]

112. Umran, N.S.S.; Mohamed, S.; Lau, S.F.; Ishak, N.I.M. Citrus hystrix leaf extract attenuated diabetic-cataract in STZ-rats. J. Food Biochem. 2020, 44, e13258. [PubMed]

113. Santiago, L.A.; Mayor, A.B. Prooxidant Effect of the Crude Ethanolic Leaf Extract of Ficus odorata Blanco Merr. In Vitro: Its Medical Significance. Int. J. Biotechnol. Bioeng. 2014, 8, 53-60.

114. Nurse, P. Checkpoint Pathways Come of Age. Cell 1997, 91, 865-867. [CrossRef]

115. Ezhevsky, S.A.; Ho, A.; Becker-Hapak, M.; Davis, P.K.; Dowdy, S.F. Differential Regulation of Retinoblastoma Tumor Suppressor Protein by G1 Cyclin-Dependent Kinae Complexes in Vivo. Mol. Cell. Biol. 2001, 21, 4773-4784.

116. Ezhevsky, S.A.; Nagahara, H.; Vocero-Akbani, A.M.; Gius, D.R.; Wei, M.C.; Dowdy, S.F. Hypo-phophorylation of the retinoblastoma protein $(\mathrm{pRb})$ by cyclin $\mathrm{D}: \mathrm{Cdk} 4 / 6$ complexes results in active pRb. Proc. Natl. Acad. Sci. USA 1997, 94, 10699-10704. 
117. Harbour, J.W.; Dean, D.C. The Rb/E2F pathway: Expanding roles and emerging paradigms. Gene Dev. 2000, 14, 2393-2409. [CrossRef]

118. He, G.; Thuillier, P.; Fischer, S.M. Troglitazone Inhibits Cyclin D1 Expression and Cell Cycling Independently of PPAR $\gamma$ in Normal Mouse Skin Keratinocytes. J. Investig. Dermatol. 2004, 123, 1110-1119. [CrossRef]

119. Hosooka, T.; Ogawa, W. A novel role for the cell cycle regulatory complex cyclin D1-CDK4 in gluconeogenesis. J. Diabetes Investig. 2015, 7, 27-28. [CrossRef]

120. Chang, C.; Su, H.; Zhang, D.; Wang, Y.; Shen, Q.; Liu, B.; Huang, R.; Zhou, T.; Peng, C.; Wong, C.C.; et al. AMPK-Dependent Phosphorylation of GAPDH Triggers Sirt1 Activation and Is Necessary for Autophagy upon Glucose Starvation. Mol. Cell 2015, 60, 930-940. [CrossRef]

121. Yang, Q.; Wang, B.; Gao, W.; Huang, S.; Liu, Z.; Li, W.; Jia, L. SIRT1 is downregulated in gastric cancer and leads to G1-phase arrest via NF-kB/Cyclin D1 signaling. Mol. Cancer Res. 2013, 11, 1497-1507. [CrossRef] [PubMed]

122. Zhou, S.; Li, M.T.; Jia, Y.Y.; Liu, J.J.; Wang, Q.; Tian, Z.; Liu, Y.T. Regulation of Cell Cycle Regulators by SIRT1 Contributes to Resveratrol-Mediated Prevention of Pulmonary Arterial Hypertension. BioMed Res. Int. 2015, 2015, 1-14. [CrossRef] [PubMed]

123. Omoregie, E.S.; Osagie, A.U. Effect of Jatropha tanjoresis leaves supplement on activities of some antioxidant enzymes, vitamins and lipid peroxidation in rat. J. Food Biochem. 2011, 35, 409-424. [CrossRef]

124. Omoregie, E.S.; Osagie, A.U. Phytochemical screening and anti-anaemia effect of Jatropha tanjoresis leaf in protein malnourished rats. Plant. Arch. 2007, 7, 509-516.

125. Shafaquat, N.; Syed, T.; Showkat, A.G. Glutathione-S-transferase, Superoxide Dismutase (GST, SOD) levels, Protein content and lipid Perioxidation in Schizothorax plagiostomus under the infection of pomphorhynchus in Nallah Sukhnag of Kashmir Valley. Pakistan. J. Biol. Sci. 2017, 20, 442-446.

126. AshokKumar, T. Antioxidants: New-generation therapeutic base for treatment of polygenic disorders. Curr. Sci. 2004, 86, 496-504.

127. Jonas, C.R.; Puckett, A.B.; Jones, D.P.; Griffith, D.P.; Szeszycki, E.E.; Bergman, G.F.; Furr, C.E.; Tyre, C.; Carlson, J.L.; Galloway, J.R.; et al. Plasma antioxidant status after high-dose chemotherapy a randomized trial of parenteral nutrition in bone marrow transplantation patients. Am. J. Clin. Nutr. 2000, 72, 181-189. [CrossRef]

128. Bahrami, S.; Jalali, M.H.; Jafari, A. Evaluation of hepatic antioxidant changes in ovine discrocoliosis. J. Parasit. Dis. 2015, 39, 766-769.

129. Deger, S.; Deger, Y.; Ertekin, A.; Gul, K.; Ozdal, N. Determination of the status of lipid perioxidation and antioxidant in Cattle infected with Dictyocaulus viviparous. Turk. Parasitol. 2008, 32, 234-237.

130. Siwela, A.H.; Motsi, L.R.; Dube, S. Alternation of some hepatic enzyme activities by gastrointestinal helminth parasite in domesticated ostrishes. Adv. Biores. 2013, 4, 145-150.

131. Pranitha, A.; Lakshmi, P.K. Effect of $\mathrm{pH}$ on weakly acidic and basic model drugs and determination of their ex vivo transdermal permeation routes. Braz. J. Pharm. Sci. 2018, 54, e00070.

132. Persson, L.C.; Porter, C.J.H.; Charman, W.N.; Bergström, C.A.S. Computational Prediction of Drug Solubility in Lipid Based Formulation Excipients. Pharm. Res. 2013, 30, 3225-3237. [CrossRef] [PubMed]

133. Agarwal, A.; Roychoudhury, S.; Sharma, R.; Gupta, S.; Majzoub, A.; Sabanegh, E. Diagnostic application of oxidation-reduction potential assay for measurement of oxidative stress: Clinical utility in male factor infertility. Reprod. Biomed. Online 2017, 34, 48-57. [CrossRef]

134. Ortiz-Prado, E.; Dunn, J.F.; Vasconez, J.; Castillo, D.; Viscor, G. Partial pressure of oxygen in the human body: A general review. Am. J. Blood Res. 2019, 9, 1-14.

135. Donovan, L.; Welford, S.M.; Haaga, J.; LaManna, J.; Strohl, K.P. Hypoxia-implications for pharmaceutical developments. Sleep Breath. 2010, 14, 291-298. [CrossRef]

136. Hussain, K.; Ismail, Z.; Sadikun, A.; Ibrahim, P. Bioactive Markers Based Pharmacokinetic Evaluation of Extracts of a Traditional Medicinal Plant, Piper sarmentosum. Evid.-Based Complement. Altern. Med. 2011, 980760, 1-7. [CrossRef]

137. Smith, D.A.; Beaumont, K.; Maurer, T.S.; Di, L. Volume of Distribution in Drug Design. J. Med. Chem. 2015, 58, 5691-5698. [CrossRef] 
138. Babu, S.; Jayaraman, S. An update on $\beta$-sitosterol: A potential herbal nutraceutical for diabetic management. Biomed. Pharmacother. 2020, 131, 110702. [CrossRef] [PubMed]

139. Liu, H.; Yang, G.; Tang, Y.; Cao, D.; Qi, T.; Qi, Y.; Fan, G. Physicochemical characterization and pharmacokinetics evaluation of $\beta$-caryophyllene/ $\beta$-cyclodextrin inclusion complex. Int. J. Pharm. 2013, 450, 304-310. [CrossRef] 